Schweizerische Eidgenossenschaft

Confédération suisse

Confederazione Svizzera

Confederaziun svizra
Eidgenössisches Departement für

Wirtschaft, Bildung und Forschung WBF

Staatssekretariat für Wirtschaft SECO

Direktion für Wirtschaftspolitik
Strukturberichterstattung

Nr. 56/2

\section{Exchange rate fluctuations} and quality composition of exports: Evidence from Swiss product-level data

Schwerpunktthema:

Die Schweizer Wirtschaft in einem schwierigen Währungsumfeld
Dario Fauceglia Björn Plaschnick Maria Rueda Maurer
Study on behalf of the State Secretariat for Economic Affairs SECO 
Schweizerische Eidgenossenschaft

Confédération suisse

Confederazione Svizzera

Confederaziun svizra
Eidgenössisches Departement für Wirtschaft, Bildung und Forschung WBF Staatssekretariat für Wirtschaft SECO Direktion für Wirtschaftspolitik

Strukturberichterstattung

Nr. 56/2

Dario Fauceglia Björn Plaschnick Maria Rueda Maurer
Exchange rate fluctuations and quality composition of exports: Evidence from Swiss product-level data

Schwerpunktthema: Die Schweizer Wirtschaft in einem schwierigen Währungsumfeld 



\title{
Exchange rate fluctuations and quality composition of exports: Evidence from Swiss product-level data
}

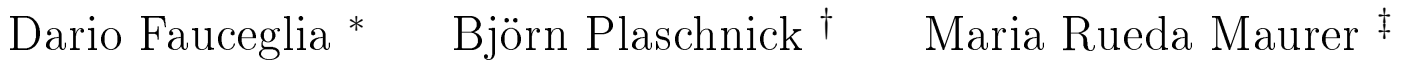

September 7, 2017

\begin{abstract}
This paper studies the relationship between exchange rate movements and the average export quality using disaggregated Swiss product-level data between 1996 and 2015. We find evidence at different levels of aggregation that the average export quality increases in response to a currency appreciation. This exchange rate effect on quality is more pronounced for differentiated goods and in sectors with a greater scope for quality differentiation. We also find empirical support for a compositional effect: Currency appreciations shift market shares towards goods that are more expensive and of higher quality. From a policy perspective, this reallocation effect points to the importance of facilitating structural changes in the export composition to increase the resilience of the export sector to exchange rate shocks. Our results also suggest a positive relationship between the average export quality and aggregate export sales. From a methodological point of view, the findings imply that exchange rate pass-through estimations without quality controls tend to be biased regardless of aggregation level or type of data.
\end{abstract}

Keywords: Exchange rate, quality, aggregate exports

\section{JEL Classification: F10, F14}

*Dario Fauceglia, ZHAW School of Management and Law, Bahnhofplatz 12, 8400 Winterthur, Switzerland. E-mail: fauc@zhaw.ch.

${ }^{\dagger}$ Björn Plaschnick, ZHAW School of Management and Law, Bahnhofplatz 12, 8400 Winterthur, Switzerland. E-mail: plas@zhaw.ch.

${ }^{\ddagger}$ Maria Rueda Maurer, ZHAW School of Management and Law, Bahnhofplatz 12, 8400 Winterthur, Switzerland. E-mail: rued@zhaw.ch 


\section{Contents}

1 Executive summary $\quad 3$

$\begin{array}{llr}2 & \text { Introduction } & 6\end{array}$

3 Theoretical background $r$

4 Measuring quality changes $\quad 10$

4.1 Estimated quality measure ........................ 11

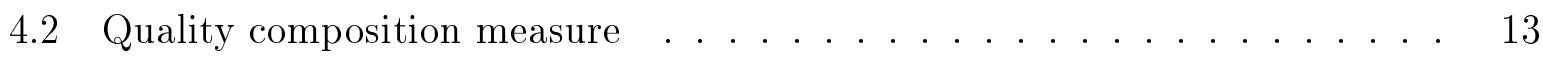

5 Estimation $\quad 14$

5.1 Econometric strategy . . . . . . . . . . . . . . . 14

5.2 Data sources and construction of the dataset . . . . . . . . 16

5.3 Descriptive statistics ............................ 17

5.4 Evidence on the relationship between exchange rate changes and product

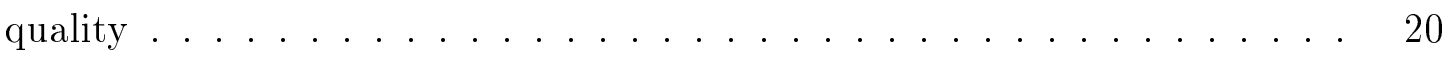

5.5 The effect of quality changes on export growth . . . . . . . . . . 28

6 Conclusions $\quad 32$

7 Appendix $\quad 36$

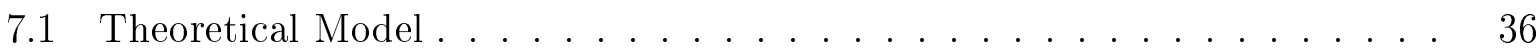

7.2 Appendix Table: Robustness to real exchange rate movements . . . . . . 39 


\section{Executive summary}

For Switzerland as a small country oriented towards export markets, the evolution of the Swiss Franc is a relevant determinant of its economic prosperity. Interestingly, even though the Swiss Franc has strongly appreciated in the sample period between 1996 and 2015, export sales have more than doubled during the same period, as illustrated in Figure 1. This apparent resilience of the Swiss export economy to exchange rate changes is usually associated with its concentration in inelastic niche markets of high-quality products, its backward linkages to international supply chains and its diversification in terms of export destinations towards higher growth markets such as China.

There is, however, no systematic study that examines how the average export quality responds to Swiss Franc appreciations. We fill this gap with this study. Our theoretical hypothesis is that the export composition shifts towards higher quality goods after a currency appreciation, which may help the Swiss export economy to remain competitive despite the steady appreciations of its currency. Theoretically, during an appreciation

episode exporters supplying lower quality goods pull out of the export market and market shares are reallocated towards exporters of higher quality goods. This results in an increase in the average export quality. This might also be an explanation for Swiss exports having the highest quality in 2007, on average $66 \%$ higher than the world average of 185 countries according to Feenstra and Romalis (2014).

\section{How to measure export quality?}

In our study we employ two different proxies for export quality, one based on export demand and the other on export prices (unit values). The quality of a product is not directly observable by the econometrician but can be inferred from observed demand behavior or export prices. In this paper, quality is understood fairly broadly as factors that shift demand for a product outward for given prices and income. Therefore, product quality is not restricted to physical characteristics of a product but is also related to advertisement, branding or the coupling of products with services such as maintenance, consulting etc. that raise the perceived product quality from the viewpoint of customers. This implies that an increase in the quality of a specific product should boost its demand compared to similar products with the same price but inferior perceived quality.

Related to this intuition, we infer the quality of exports understood as a demand shifter 
based on the estimation of an export demand function in our first measure. Specifically, we control for price and income in the demand estimation and recover quality from the estimated residuals accordingly (at the very disaggregated HS 8-digit level). These residuals capture all factors that shift demand and cannot be attributed to relative price or income changes in the export destination.

In a second quality indicator we measure changes in market share weighted (average) export prices within narrowly defined product groups (at the HS 6-digit and HS 4-digit level). If market shares shift towards higher priced goods, the average export price goes up and this is interpreted as an increase in the average export quality within a narrow product group. Export prices are a valid quality indicator since most variation in export prices can be explained by quality differences according to the trade literature (see for instance Feenstra and Romalis, 2014).

\section{Currency appreciations induce quality improvements with both quality mea- sures}

We use product-level bilateral trade data between 1996 and 2015 obtained from the Swiss Federal Customs Administration (Eidgenössische Zollverwaltung) to estimate the effect of exchange rate movements on product quality. The empirical findings with both quality measures are similar and suggest that a currency appreciation increases the observed average export quality. In contrast, a currency depreciation reduces the exported quality. We also find evidence for a composition effect in the sense that higher priced goods gain market shares at the expense of lower prices goods in the wake of a currency appreciation. Specifically, we find an estimated effect of a Swiss Franc appreciation on quality between 0.1 and 0.2 with the first quality measure based on demand residuals. That is, a $10 \%$ appreciation raises the average export quality at the HS 8-digit level by about $1 \%$ to $2 \%$. The exchange rate driven quality effect is particularly pronounced for differentiated goods and in sectors that are intensive in R\&D and advertisement. For instance, while quality does not respond to exchange rate changes in sectors with more homogeneous goods and stronger price competition such as natural resources, a currency appreciation results in significant quality improvements in sectors such as machinery and precision instruments (incl. watches) with a greater scope for quality differentiation (see Figure 4). Another interesting finding is the positive correlation between sectoral imported input prices and export quality, which is consistent with a switching of Swiss exporters to more expensive imported inputs in order to produce higher quality export goods. 


\section{Secular trends and growth markets lower the exchange rate driven effect on quality}

The relationship between $R \& D$ and advertisement intensity and the strength of the exchange rate driven effect on quality does not hold for all sectors: When we drop the chemical and pharmaceutical sector from the estimating sample, the effect of exchange rate movements on quality becomes somewhat larger. Quality adjustments in this sector may be more related to secular trends such as the long-term increase in health expenditures and changes in the regulatory environment rather than exchange rate fluctuations.

We also find that an increase in market size - approximated by a rise in real GDP in the export market - tends to reduce the average export quality. This is consistent with the idea that larger and growing markets also allow exporters of lower quality goods to enter an export market, and thereby lowering the overall quality exported to this destination. This provides additional evidence that the adjustment in the exporters' selection plays an important role in triggering changes in the average export quality.

\section{Economic policy should facilitate rapid structural changes of the export sector}

Our results suggest that currency appreciations increase the market shares of higher quality goods in Swiss exports. Moreover, we could show that a higher export quality also raises average export sales and, therefore, shields exporters of higher quality products from excessive price competition in foreign markets. From a policy perspective, this reallocation of market shares towards higher quality goods points to the importance of facilitating structural changes in the export composition in order to cushion the adverse effects of currency appreciations. 


\section{Introduction}

A large part of the exchange rate related literature has emphasized the direct effect of currency movements on aggregate prices and quantities (Burstein and Gopinath, 2013). Scholars have paid particular attention to the phenomenon of incomplete pass-through; the stylized fact that exchange rate shocks are in the majority of cases only partially transmitted to foreign consumers. Apart from imported inputs, distribution and other costs in local currency, heterogeneity in terms of firm productivity and product quality can explain pricing-to-market behavior and incomplete pass-through to local prices in a variable mark-up framework (Berman et al., 2012; Chen and Juvenal, 2014). Relatedly, this paper studies the effect of a currency appreciation on the average quality of exports that arises due to shifts in the export composition. This is also relevant from a policy point of view since adjustments of the quality composition of exports may be a dynamic channel through which an economy remains competitive after a currency appreciation. This would be particularly important for a high-wage country such as Switzerland that faces steady appreciations of its currency. The appreciation trend of the Swiss Franc is displayed in Figure 1, which shows the evolution of the Swiss Franc against the USD, the Euro and a trade-weighted basket of currencies in the sample period between 1996 and 2015. Despite the Swiss Franc's tendency to appreciate over time, export sales have more than doubled during this period, as illustrated in Figure 1.

This apparent resilience of the Swiss export economy to exchange rate changes is usually associated with its concentration in inelastic niche markets of high-quality products (Auer and Saure, 2011), its backward linkages to international supply chains (Fauceglia et al., 2014b,a) and its diversification in terms of export destinations towards higher growth markets such as China. There is, however, no systematic study that addresses the response of the average export quality to a Swiss Franc appreciation as a margin of adjustment. Auer and Saure (2011) document that Swiss exports are indeed concentrated in price-insensitive sectors, but they do not analyze how the export composition reacts to the exchange rate. At the firm-level, Kaiser and Siegenthaler (2016) find evidence that Swiss exporters demand more skilled labor, increase R\&D expenditures and the outsourcing of simpler tasks after a Swiss Franc appreciation. Their findings thus suggest that firms adjust the product quality upwards when the Swiss Franc appreciates. This study provides complementary evidence with product-level customs data that the average export quality increases at different levels of aggregation (HS 8-digit to HS 4-digit category) during Swiss Franc appreciation 
Figure 1: Export sales and CHF nominal exchange rate indices $(1996=100)$

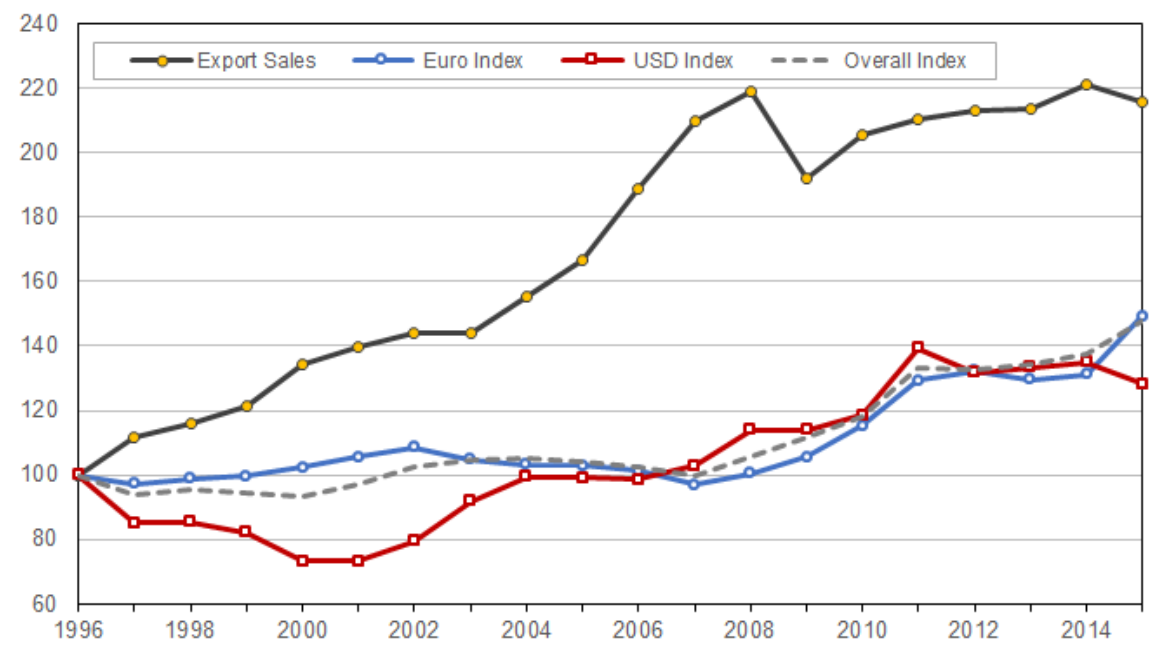

Source: SNB

periods. ${ }^{1}$ This is driven by gains of market shares of higher quality varieties at the expense of lower quality varieties within narrowly defined product categories. Moreover, exchange rate driven quality responses are particularly pronounced for differentiated goods and in sectors intensive in R\&D and advertisement. Our results are consistent with a qualityaugmented Melitz (2003)-model presented in Section 3 that emphasizes a pure selection effect as the main driver of quality upgrading. In this model, a currency appreciation raises the capability (ratio of product quality to marginal cost of production) cutoff for the marginal exporter. ${ }^{2}$ As a result, less capable exporters that are not able to provide the higher required quality to thrive in this more competitive environment pull out of the export market. This selection effect increases the average export quality to a given destination through a shift in the export composition towards higher quality goods.

From a policy point of view, this export composition effect also indicates the importance of facilitating rapid structural changes in the set of exported goods in order to maintain a responsive and resilient export sector. The empirical results also reveal that a higher quality boosts export sales even at higher aggregation levels and reduces the negative effect

\footnotetext{
${ }^{1}$ We employ nominal exchange rate indices in the empirical part because these are the theoretically relevant exchange rates according to our theoretical framework. They also exhibit more variation to exploit empirically than real exchange rates. Importantly, however, all main conclusions also hold when we use real exchange rates as described in Section 5.4 (see also the Appendix Table in Section 7.2 for robustness checks to real exchange rate specifications).

${ }^{2}$ The marginal exporter is the least capable exporter that still satisfies the zero-profit condition.
} 
of higher prices on export demand, particularly for differentiated goods and in sectors with a greater scope for quality differentiation. In this sense, Swiss exporters that provide a higher product quality are at least partly shielded from excessive price competition in export destinations.

To sum up, this study establishes quality as an additional margin of adjustment in response to an appreciating currency for which there is still scant evidence. ${ }^{3}$ From a methodological point of view, the results suggest that estimations of the pass-through rate that do not control for simultaneous quality changes tend to be biased upward regardless of the level of aggregation or type of data.

\section{Theoretical background}

The seminal paper by Melitz (2003) and its quality extensions (see for instance Baldwin and Harrigan, 2011; Johnson, 2012; Feenstra and Romalis, 2014) constitute the theoretical foundation of our regression analysis (see also Section 7.1 in the Appendix for a formal theoretical model). In the original Melitz (2003)-model firms differ in terms of their productivity, which is inversely related to the marginal cost of production. That is, a firm with a high productivity has a low marginal cost of production. The productivity of each firm is drawn randomly from some known statistical distribution prior to starting production. However, some firms exit the home market immediately since their productivity draw is not sufficiently high to generate positive (or non-negative) profits. To serve an export market firms must incur a fixed cost related to establishing a logistics network, a brand, compliance with local law etc. in addition to variable production and trade costs. Because of the presence of this fixed cost of market entry, only a subset of sufficiently productive firms (among those surviving) will be able to export profitably. These firms benefit from a trade liberalization due to an expansion of export demand, while the least productive firms suffer from the additional competition of foreign firms and exit. As a result, a trade liberalization induces market share reallocations towards more productive firms that generate aggregate productivity gains, which is the main insight of the Melitz (2003)-model.

\footnotetext{
${ }^{3}$ Our results are in line with Auer and Chaney (2009) who also provide weak evidence for quality upgrading of products exported to the US when the exporter's currency appreciates. In contrast, Verhoogen (2008) shows that an exchange rate depreciation induces Mexican firms with higher abilities to upgrade their quality and to pay higher real wages. In our view, his results are not directly comparable to ours since Mexico is substantially poorer than Switzerland. In addition, the sample period of his study coincides with the period in the aftermath of the Tequila crisis in which Mexico was affected by massive capital outflows, while Switzerland's appreciation episodes in our sample are driven by capital inflows.
} 
While in the original Melitz (2003)-model exporters and non-exporters only differ in terms of marginal cost of production ("productivity"), we add a quality dimension to firms to explain the effect of exchange rate movements on the average export quality. A higher product quality acts as demand shifter so that firms with relatively higher quality earn higher profits as compared to firms supplying lower quality with the same marginal cost structure. As a consequence, the partition between exporters and non-exporters is driven by the ratio of product quality to marginal cost of production, which we may denote as firm "capability". A high capability firm with a high ratio of quality to marginal cost generates higher profits that a low capability firm. In Figure 2 we draw a normal distribution of firm capabilities with a capability cutoff determined by the zero-profit condition for the marginal exporter. In other words, the marginal exporter has a sufficiently large ratio of product quality to marginal cost that allows her to accrue enough operating profits (= revenues minus variable costs) in the export market to cover the recurring fixed cost of exporting ("zero profit"). This implies that only firms above this ratio of product quality to marginal cost enter the export market profitably and determine the average export quality of a country. We also assume that firm capability and product quality are positively correlated so that the export quality increases along the capability dimension. As a consequence, a higher capability cutoff shifts the firm composition towards more capable exporters and, therefore, raises the average export quality of a country.

What would be the effect of a currency appreciation in this framework? A currency appreciation reduces export revenues whenever demand for a firm's product in the export market has a negative slope. This leads to reduced export profit margins for all exporters under the assumption that at least part of the costs are incurred in the exporter's currency (so that there is no full "natural hedging"). Graphically, the currency appreciation shifts the capability cutoff to the right, as displayed in Figure 2, because it now requires a higher ratio of product quality to marginal cost to meet the zero-profit condition for the export market. Consequently, some of the least capable exporters already close to "zero profits" before the appreciation would now make losses abroad and thus are forced to pull out of the export market altogether. The stronger currency therefore reallocates export market shares towards more capable firms that supply higher quality products and are still able to make profits abroad in this more competitive environment. Put differently, a currency appreciation induces a selection and composition effect that raises the average export quality of a country. This is the main prediction that we test later empirically in Section 5 .

We also examine the relationship between market size and average export quality. As 
Figure 2: Firm distribution of capabilities and cutoff for export market entry

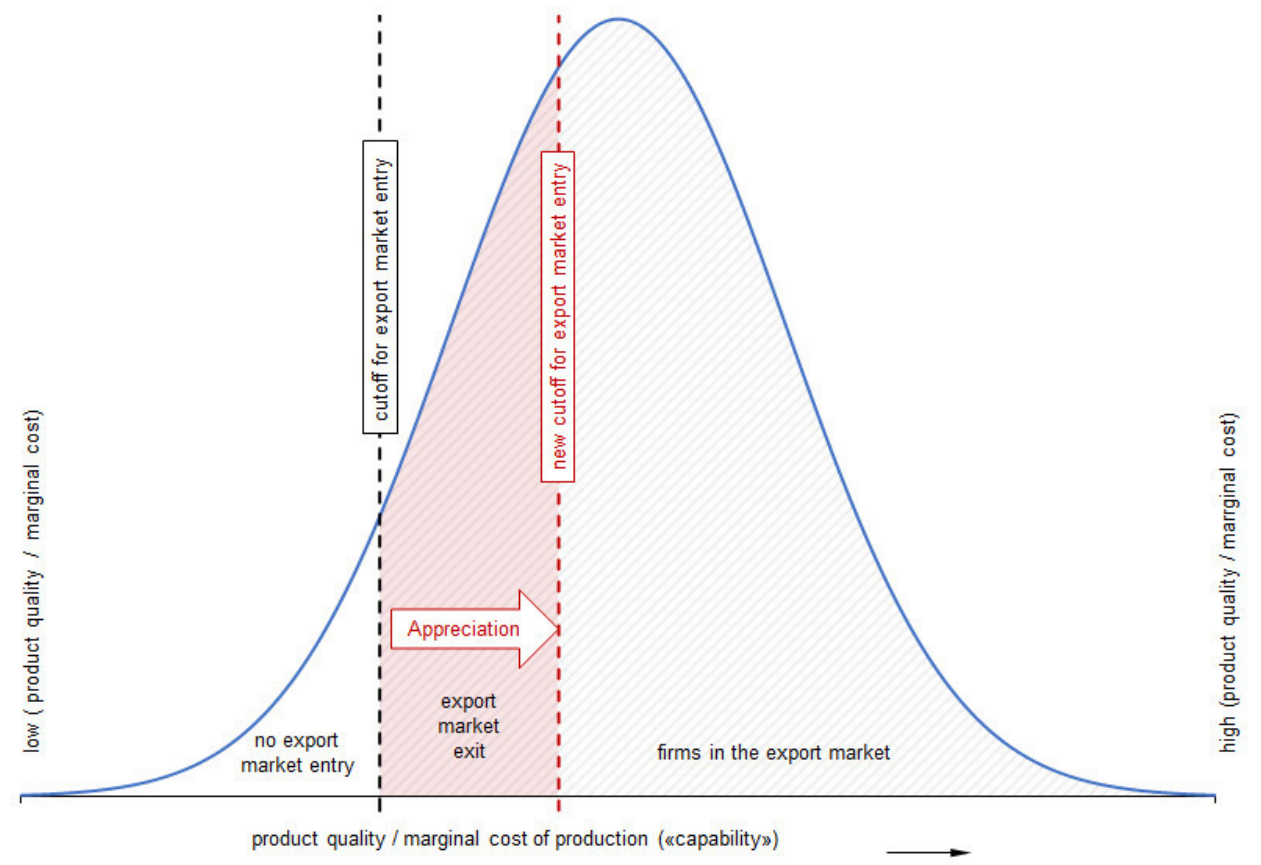

demand rises in the export market - approximated by a rise in real GDP - export revenues and profits tend to rise, implying a shift of the capability cutoff to the left, which promotes the entry of less capable exporters (see also Feenstra and Romalis, 2014). It follows that the average export quality is predicted to fall in response to a rise in foreign GDP. Support for this relationship would provide additional evidence that adjustments in the composition of exporters play an important role in triggering changes in the average export quality.

\section{Measuring quality changes}

This section presents two different measures of export quality that are later used in Section 5 to examine the relationship between exchange rate movements and quality. The first measure recovers quality from the regression residual of an export demand function (see Section 4.1), while the second measure employs export unit values to infer product quality (see Section 4.2).

The quality of a product is not directly observable by the econometrician but can be inferred from observed demand behavior or export prices. ${ }^{4}$ In this paper, quality is under-

\footnotetext{
${ }^{4}$ Feenstra and Romalis (2014) also apply supply-side conditions to estimate the export quality.
} 
stood fairly broadly as product-related factors that shift demand for this product outward. This implies that an increase in the quality of a specific product should boost its demand compared to similar products with the same price but inferior perceived quality. In other words, customers prefer the product with the highest perceived quality in a set of equally priced substitutes. This is also the intuition behind the method proposed by Khandelwal et al. (2013) that we employ to infer product quality in Section 4.1. Relatedly, higher quality products can command higher export prices because their price elasticities tend to be lower in comparison with low quality products. More generally, in our understanding product quality is not restricted to physical characteristics of a product and, consequently, can be improved by other means than (long-term) product innovation as well. Quality improvements are, for example, also related to advertisement intensity, branding and placement of a product. These marketing practices aim to raise customers' willingness to pay for a product that is promoted as superior relative to peer group. Similarly, the coupling of manufacturing products with related services ("servicification") such as maintenance, repair, surveillance, consulting or product customization is becoming increasingly important in the process of quality upgrading. Firms can gain a competitive advantage and establish more durable relationships with their customers through services that help them differentiate from competitors (Low, 2013). As a result, providing services in addition to the physical product is likely to foster the perceived product quality from the viewpoint of customers.

\subsection{Estimated quality measure}

Our first quality measure is based on an adaption of the method proposed by Khandelwal et al. (2013). Apart from prices and income in the destination market, export demand for a specific export product also depends on quality understood as a demand shifter. Therefore, we can estimate a demand function that controls for price and income differences and recover quality from the estimated residuals accordingly. Those residuals capture all factors that shift demand and cannot be attributed to relative price or income changes in a given export destination.

More formally, we define an export demand $x_{i c t}$ at the observed product-level $i$ (HS 8digit level) that depends (positively) on the product quality $q_{i c t}$, (negatively) on price $p_{i c t}$ relative to the price index $\widetilde{P_{c t}}$ and positively on income $E_{c t}$ in destination $c$ and year $t$, with $\sigma$ being the elasticity of substitution between products: 


$$
x_{i c t}=q_{i c t}^{\sigma-1} p_{i c t}^{-\sigma} \widetilde{P}_{c t}^{\sigma-1} E_{c t}, \quad \sigma>1
$$

We can use an exchange rate $\varepsilon_{c t}$, defined as foreign currency over domestic currency, and trade $\operatorname{costs} \tau_{c t}(>1)$ to link unobserved prices in destinations $p_{i c t}$ to observed free on board (fob) export unit values $p_{i c t}^{f o b}$ ("export prices"). Specifically, using $\varepsilon_{c t} \tau_{c t} p_{i c t}^{f o b}=p_{i c t}$ we can describe the observed demand at the destination-product level in equation (1) in log-linear form as follows:

$$
\begin{gathered}
\ln \left(x_{i c t}\right)+\sigma \ln \left(p_{i c t}^{f o b}\right)=(\sigma-1) \ln \left(\widetilde{P}_{c t}\right)-\sigma \ln \left(\varepsilon_{c t} \tau_{c t}\right)+\ln \left(E_{c t}\right)+(\underbrace{\sigma-1) \ln \left(q_{i c t}\right)}_{=e_{i c t}} \\
\ln \left(x_{i c t}\right)+\sigma \ln \left(p_{i c t}^{f o b}\right)=\alpha_{i}+\alpha_{c t}+(\underbrace{\sigma-1) \ln \left(q_{i c t}\right)}_{=e_{i c t}}
\end{gathered}
$$

We estimate equation (3) with destination-time fixed effects $\alpha_{c t}$ that control for changes in expenditures $\left(E_{c t}\right)$ and aggregate price movements $\left(\widetilde{P}_{c t}\right)$ in the destination country. Moreover, these destination-time fixed effects also absorb trade costs $\left(\tau_{c t}\right)$, and exchange rate changes $\left(\epsilon_{c t}\right)$ over time. Since different HS 8-digit products $i$ may not be comparable among them, the $\alpha_{i}$ fixed effects capture fundamental differences across HS 8-digit products. The basic idea of this method is intuitive: Conditional on relative product price and income in the destination country, increases in demand within a HS 8-digit product are associated with a higher quality. Put differently, the quality of a product is identified from demand changes within a HS 8-digit product for a given fob export price after controlling for price index, income, tariff and exchange rate changes. After estimating equation (3), the quality of exports is then calculated from predicted residuals $\hat{e}_{i c t}$ :

$$
\ln \left(\hat{q}_{i c t}\right)=\frac{\hat{e}_{i c t}}{\sigma-1}
$$

To obtain the time-varying predicted quality at the highest level of disaggregation in our data, $\ln \left(\hat{q}_{i c t}\right)$ in equation (4), we use the elasticities of substitution $\sigma_{k}$ from Imbs and Méjean (2015) available at the the 3-digit ISIC (Revision 2) sector level that also includes Switzerland in the country sample. The sigmas $\sigma_{k}$ measure the responsiveness of the average demand in a sector $k$ to relative price changes, which depends on the substitutability of goods within a specific sector. Higher sigmas imply a higher demand responsiveness to price changes. In a robustness check, we employ the sigmas from Soderbery (2015) to check 
for the sensitivity to different elasticity estimates. Imbs and Méjean (2015) and Soderbery (2015) use different estimation techniques to deal with the endogeneity of price changes and aggregation or small sample biases that would lead to inconsistent sigma estimates if not properly addressed. ${ }^{5}$

\subsection{Quality composition measure}

We construct a second quality measure that is based on export unit values, as widely applied in the literature (see for example Hallak, 2006; Hummels and Klenow, 2005; Manova and Zhang, 2012). Even though differences in fob export unit values at the HS 8-digit level may reflect differences in production costs and pricing strategies across varieties (Henn et al., 2013), most of the variation in unit values can be attributed to quality changes according to Feenstra and Romalis (2014) (see also Hallak, 2006). ${ }^{6}$ The idea that the variation of export unit values is predominantly driven by quality differences is also supported by the positive relationship between export prices and sales obtained in Section 5.5 that is consistent with the empirical findings of Baldwin and Harrigan (2007) and Manova and Zhang (2012). This result can only be reconciled with quality-augmented versions of the Melitz(2003)-model in which a higher export price reflects a higher product quality. ${ }^{7}$

Specifically, we adapt a measure introduced by Auer and Chaney (2009) to approximate for changes in the average export quality:

$$
\triangle \text { Quality }_{h s 4 c t}=\sum_{\omega \in \Omega_{t} \cap \Omega_{t-1}}\left(s_{i c t}-s_{i c t-1}\right) \times \ln \left(p_{i c t-1}^{f o b}\right)
$$

where $s_{i c t}$ and $s_{i c t-1}$ denote the market shares of HS 8-digit products $i$ in time $t$ and $t-1$ within a HS 4-digit product group $\Omega$ in a given destination $c$. Export prices (unit values)

\footnotetext{
${ }^{5}$ Imbs and Méjean (2015) employ the novel tetrad method proposed by Caliendo and Parro (2014) to estimate the trade elasticities, while Soderbery (2015) relies on a limited information maximum likelihood estimator (LIML) combined with a constrained nonlinear LIML routine.

${ }^{6}$ Feenstra and Romalis (2014) show that more developed countries export more expensive goods relative to poorer countries. In contrast, quality-adjusted export unit values tend to be only slightly higher for developed countries, indicating that most of the variation in export unit values is explained by quality.

${ }^{7}$ Moreover, empirical evidence (see for instance Johnson, 2012) suggests that the quality of a product often increases disproportionately with firm capability. This translates to $\theta>1$, which implies that product quality and observed free on board export prices are positively correlated, as can be seen from the following relationship: $p_{i c t}^{f o b}(q)=\left(\frac{\sigma}{\sigma-1}\right) q_{i c t}^{\frac{\theta-1}{\theta}}$. This indicates that export prices are valid quality approximations of the underlying products within a relatively narrowly defined product group if $\theta>1$ holds. This condition is more likely to hold for more differentiated goods.
} 
$p_{i c t-1}^{f o b}$ in period $t-1$ are intended to capture quality differences of destination-specific HS 8-digit products within a product group. We use lagged export prices $\left(p_{i c t-1}^{f o b}\right)$ from the period $t-1$ to ensure that unit values are not affected by contemporaneous exchange rate and other cost and demand shocks. In addition, only products that are exported in both periods $t$ and $t-1$ are considered so that the market shares $s_{i c t}$ and $s_{i c t-1}$ sum to unity. A positive change, $\triangle$ Quality $_{h s 4 c t}>0$, reflects rising export market shares of more expensive HS 8-digit products within a product group. This would be interpreted as an increase in the average export quality of a destination-specific product group in period $t .^{8}$ Quality changes defined as in equation (5) are thus driven by product composition effects within narrowly defined HS4-digit product groups. ${ }^{9}$ For example, the HS 4-digit code 6106 corresponds to "Women's or girls' blouses 8 shirts, knit or croch", which contains the HS 6-digit code 610610 "Women's or Girls' Blouses, Shirts, of Cotton, Knitted or Crocheted" among others. Calculating $\triangle$ Quality $_{h s 4 c t}$ at the narrower HS 6-digit level would have resulted in a much lower variability of this measure because in many cases there is only one HS 8-digit product exported to a given destination within each HS6-digit product category. However, the significance of the results is not sensitive to using the quality composition measure computed at the HS 6-digit level, as robustness checks will show.

\section{Estimation}

\section{$5.1 \quad$ Econometric strategy}

We estimate the following equation to examine the effect of exchange rate movements on the observed average quality of exported products $i$ (defined at 8-digit, 6-digit or 4-digit of the HS category) to destination country $c$ and year $t$ :

$$
\triangle Q_{i c t}=\beta \triangle \ln E R_{c t}+\gamma \triangle \ln G D P_{c t}+\delta \triangle \ln \operatorname{ProdPrice}{ }_{k t}+\rho \operatorname{Share}_{i c t}\left(H H I_{i c t}\right)+\lambda_{i c}+\eta_{t}+\varepsilon_{i c t}
$$

\footnotetext{
${ }^{8}$ For example, we have two similar products with prices $p_{1}=5$ and $p_{2}=6$ and equal market shares $s_{1}=s_{2}=0.5$ in period $\mathrm{t}-1$. In period t the market share of the more expensive variety increases to $s_{2}=0.6,\left(s_{1}=0.4\right)$ so that we obtain the following increase in the average quality change: $(0.6-0.5) *$ $6+(0.4-0.5) * 5=+0.1$.

${ }^{9}$ There are about 1200 HS 4-digit product groups in our sample.
} 
The dependent variable $\triangle Q_{i c t}$ corresponds to the first difference of the demand residual quality estimate $\left(\ln \left(\hat{q_{\text {ict }}}\right)\right)$ from Section 4.1 in Tables 2 and 3 and to the quality composition measure $\left(\triangle\right.$ Quality $\left._{h s 4 c t}\right)$ from Section 4.2 in Tables 4 and 5 . The first-difference model (6) can be viewed as a transformed fixed effects model that controls for unobserved heterogeneity at the destination-product level but also considers the likely persistence of explanatory variables such as exchange rates, GDP series and prices (Wooldridge, 2002). Time-invariant destination-specific factors such as distance that might affect export quality (e.g. the Alchian-Allen conjecture for which there is evidence in Hummels and Skiba, 2004) are absorbed as well in this specification. A currency appreciation $(\triangle \ln E R \uparrow)$ is expected to have a positive effect on average export quality according to our theoretical motivation, implying $\beta>0$ after taking into account the evolution of real GDP in export countries over time and Swiss production cost changes $(\triangle \ln$ ProdPrice $k t)$ measured at the 2-digit sector-level $k$ of the ISIC classification. Share ${ }_{i c t}$ denotes the HS 8-digit product market share relative to all Swiss products sold in a country within a given HS 4-digit category. This market share variable controls for changes in the competitive pressure that a specific product faces in a given destination compared to its Swiss competitors, as in Amiti et al. (2014) and Manova and Zhang (2012). In the estimations using the quality composition measure (Section 4.2) at the more aggregated level, we are able to compute the more commonly used (destination-specific) Herfindahl index $\left(H H I_{i c t}\right)$ that measures market concentration of HS 8-digit products within a given HS 4-digit category, as in Fan et al. (2015). ${ }^{10}$ Among others, changes in the product variety and competitive stance in a destination market stemming from trends in the supply of domestic and imported products from other countries, are captured by time trends at the destination-product level $\left(\lambda_{i c}\right) .{ }^{11}$ We also employ time fixed effects $\eta_{t}$ to absorb common trends that affect the quality of all exports similarly (e.g. the increasing importance of after-sales services). Standard errors are in most specifications clustered at the destination-sector (2-digit HS) level. This allows errors to be correlated over time and cross-sectionally within relatively large sectors. The idea is that the exchange rate might affect the export quality similarly within 2-digit HS sectors (Moulton, 1990). Moreover, clustering at the destination-sector level rather than at the destination level prevents us from having too few clusters. However, the significance of the main results is not sensitive to clustering at a more fine-grained destination-product

\footnotetext{
${ }^{10}$ Specifically, the HHI is computed by summing the squares of the HS 8-digit market shares of Swiss HS8-digit products in a given destination and HS 4-digit category.

${ }^{11}$ The fixed effects $\lambda_{i c}$ correspond to linear time trends at the destination-product level in the firstdifference model. Similarly, the included intercept also corresponds to a linear time in this model.
} 
level. We also test the robustness of the results in dynamic models by employing the GMM estimator introduced by Arellano and Bond (1991). This GMM framework permits to consider serial correlation of quality changes and the potential endogeneity of exchange rate changes.

\subsection{Data sources and construction of the dataset}

Product-level bilateral trade data between 1996 and 2015 is obtained from the Swiss Federal Customs Administration and include the fob value of transactions in CHF and a quantity measured in $\mathrm{kg}$ disaggregated at the HS 8-digit level. This allows to generate fob unit values as a proxy for export prices that are necessary to estimate and construct the quality measures presented in Section 4. We reduce the dataset to the 37 most important trading partners of Switzerland, including all OECD countries and the BRICS that account for more than 90 percent of Swiss exports. The monthly recorded transactions are collapsed to annual data by summing revenues and quantities over disaggregated HS8-digit product categories within export destinations. We then match the customs data with exchange rate indices calculated with data from the Swiss National Bank (SNB). GDP and GDP per capita are retrieved from the World Development Indicators database. Producer price indices at the ISIC 2-digit level (Revision 3.1) are taken from the Swiss statistical agency (BFS) and matched to our dataset classified in HS categories with the use of correspondence tables provided by the UN statistics division. Similarly, we construct sectoral imported input prices for each period by calculating a weighted sum of sectoral import price indices $I M P_{s i}$ taken from BFS, $I M P_{s o}=\sum_{s i}\left(I M P_{s i} \cdot R_{s o}^{s i}\right)$, with the weights $R_{s o}^{s i}$ corresponding to the imported input share from sector si to total imported inputs in each output sector so. These import shares are computed from the 2001 I-O table for Switzerland available from the OECD (OECD, 2012). ${ }^{12}$ We use the Rauch (1999)-classification to define goods that can be differentiated for technological reasons. Specifically, products are classified as differentiated if they are not traded on an organized exchange or referenced priced. As an example, footwear in general will be classified as differentiated, while industry metals, which are mostly traded on an organized exchange, or synthetic fibres such as polymers with a reference price are treated as homogeneous. In addition, we also employ the sectoral

\footnotetext{
${ }^{12}$ We use the chronologically first I-O table for Switzerland that is available for the sample period. In addition, the sectoral imported input shares, $R_{s o}^{s i}$ in total imported inputs used to construct sectoral import price indices $I M P_{\text {so }}$ tend to be very stable over time and mainly affected by slow-changing technological factors. For instance, there is an almost perfect correlation - coefficient of 0.99 - between the $R_{s o}^{s i}$ from the 2001 and 2005 I-O table.
} 
Table 1: Summary Statistics of Estimation VARiables

\begin{tabular}{|l|c|c|c|c|c|}
\hline Variables & Obs. & Mean & Std.Dev. & Min & Max \\
\hline \hline$\triangle$ Quality (demand residual based) & 1346820 & 0.00 & 1.701 & -58.753 & 68.091 \\
\hline$\triangle$ Quality (unit value based) & 446,492 & -0.029 & 1.041 & -13.90 & 11.94 \\
\hline$\triangle$ Exchange rate & 1346820 & 0.030 & 0.087 & -0.209 & 0.895 \\
\hline$\triangle$ Real GDP (destination) & 1346820 & 0.024 & 0.029 & -0.096 & 0.133 \\
\hline$\triangle$ Real GDP per capita (destination) & 1346820 & 0.018 & 0.028 & -0.094 & 0.128 \\
\hline$\triangle$ Production prices (CH) (2-digit ISIC) & 1346820 & 0.0006 & 0.033 & -0.381 & 0.347 \\
\hline$\triangle$ Imported input prices (CH) (2-digit ISIC) & 1346490 & -0.003 & 0.058 & -0.283 & 0.176 \\
\hline Market share (in HS4ector \& destination) & 1346820 & 0.291 & 0.358 & 0 & 1 \\
\hline Herfindhal index (HHI) (of HS4 \& destination) & 446,492 & 0.729 & 0.270 & 0.048 & 1 \\
\hline R\&D and advertisement intensity & 1175982 & 0.032 & 0.025 & 0.002 & 0.166 \\
\hline Differentiated goods dummy & $1,328,779$ & 0.752 & 0.432 & 0 & 1 \\
\hline
\end{tabular}

R\&D and advertisement measure from Kugler and Verhoogen (2012). It is calculated as the ratio of sectoral expenditures on $R \& D$ and advertising to total sales. As the scope for quality differentiation is largely driven by sectoral technological factors common across countries, we argue that it is reasonably approximated by this measure calculated with US data in line with the trade literature (see for instance Fan et al., 2015 or Bas and StraussKahn, 2015). ${ }^{13}$ We ensure the consistency of the the product classification at the HS 8-digit level by applying an algorithm similar to the one outlined in Pierce and Schott (2012) that replaces obsolete codes with time-consistent codes for each product in our data. This procedure is necessary since the Swiss HS 8-digit classification underwent several major changes, the most significant ones coinciding with the revisions of the international HS 6-digit classification in 2002, 2007 and 2012, which resulted in the assignment of new codes to a substantial number of HS 8-digit products. All these data are summarized in Table 1.

\subsection{Descriptive statistics}

Both quality measures in Table 1 display upward and downward movements with no clear trend during the sample period. We also observe that the bilateral nominal exchange rate indices exhibited both periods of depreciations and appreciations. GDP and GDP per capita in destination countries rose (by $2.4 \%$ and $1.8 \%$ respectively) on average during the

\footnotetext{
${ }^{13}$ For instance, for iron the value of this measure is $0.6 \%$, while for watches it is $4.6 \%$.
} 
sample period. The same also holds for production prices $(0.06 \%)$ in Switzerland, while imported input costs fell (-0.03\%) in Switzerland between 1996 and 2015, on average. The mean expenditures on R\&D and advertisement to total sales is around $3.2 \%$ in the sample, while around $75 \%$ of destination-product pairs are classified as differentiated as opposed to homogeneous goods. These two values are similar to the US and indicate the relatively high scope for quality differentiation in Swiss exports (Rauch, 1999; Kugler and Verhoogen, 2012). This is also reflected in Switzerland featuring the highest export quality, being on average $66 \%$ higher than the world average of 185 countries in 2007 . In comparison, exports from Japan, the US and most other developed European countries exhibit $15 \%$ to $30 \%$ higher export quality than average (Feenstra and Romalis, 2014). ${ }^{14}$ To provide an illustration of the quality evolution over the sample period, we present the export price distribution in 1996 and 2015 in Figure 3. More specifically, we plot the price residuals for both years recovered from regressing prices on HS 8-digit product fixed effects, as in De Loecker et al. (2012). ${ }^{15}$ Even though there is a statistically significant shift of the distribution to the right, quality appears to be be only marginally affected over the course of the sample period. This suggests that there might be opposite forces on quality that might cancel each other out, but not excluding a significant effect of the exchange rate on quality. This is exactly what emerges from the regression analysis presented in the next section.

\footnotetext{
${ }^{14}$ Similarly, in another ranking Swiss exports are ranked 4th in 2003 in terms of quality behind Finland (3rd), Singapore (2nd) and Ireland (1st) (Hallak and Schott, 2008).

${ }^{15}$ This descriptive method for displaying the quality distribution is widely applied in the trade literature (see for instance Bas and Strauss-Kahn, 2015 and Fan et al., 2015) and relies on unit values, as our second quality measure presented in Section 4.2.
} 
Figure 3: Export price residuals as a proxy for the quality distribution

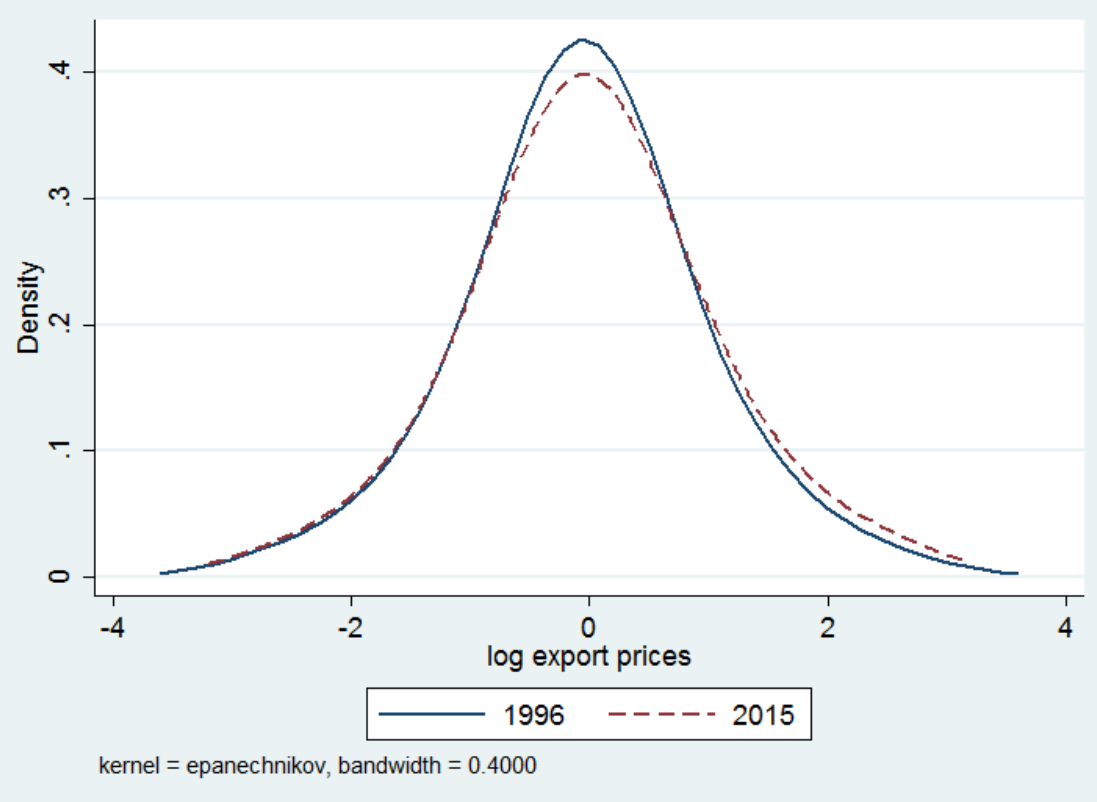




\subsection{Evidence on the relationship between exchange rate changes and product quality}

Table 2 presents the regression results on the relationship between exchange rate changes and the adjustment of product-level quality. The dependent variable corresponds to the change in the (natural) log of quality at the HS 8-digit category, as estimated in Section 4.1. Column 1 of Table 2 suggests that a currency appreciation translates into a higher export quality after controlling for real GDP changes in destination countries and sectoral production price changes in Switzerland. This result is robust to the inclusion of time trends at the destination-product level in column 2. From column 3 and 4 we see that adding the product market share within a given destination and 4-digit HS product category does not affect the size and significance of the exchange rate effect on quality. A higher product market share is associated with a higher quality of the exported products. One possible interpretation is that higher market power provides the financial means to foster product quality. But it could well be that causality runs from increased product quality to higher market shares. Column 5 to 8 reveal that the positive impact of an appreciation on export quality is more pronounced for differentiated products and concentrated in sectors with an R\&D and advertisement intensity above the sample median. A 10\% CHF appreciation increases the average product quality by about $1 \%$ to $1.6 \%$ in products and sectors with a greater scope for quality differentiation, while the exchange rate effects turns out to be insignificant or even negative for homogeneous products or sectors that rely less on R\&D and advertisement and compete more on prices. We display in Figure 4 the exchange rate elasticity of the average export quality as a function of sectoral shares of $R \& D$ and advertisement expenditures in total sales estimated with the empirical model of column 7. It indicates that only firms belonging to sectors that spend more than approximately $2.5 \%$ of their revenues on $\mathrm{R} \& \mathrm{D}$ and advertisement such as machinery, watches or precision instruments respond to an exchange rate shock by improving the export quality. In contrast, in sectors such as textiles, footwear, furniture or in commodities like basic metals or agricultural goods an appreciation does not have a significant effect on product quality. ${ }^{16}$ With regard to control variables, it is evident that higher production costs are consistently related to higher export quality. Conversely, increases in market size proxied by changes in real GDP tend to reduce the average export quality to a given destination, at least in estimations without destination-product time trends (columns 3,5 and 7 ). This result is

\footnotetext{
${ }^{16}$ In the estimations for Figure 4 we omit the top $10 \%$ of the sample distribution for which this indicator exhibits a disproportionately large dispersion.
} 
Table 2: Relationship between exchange rate changes and quality at the HS 8-digit level

\begin{tabular}{|c|c|c|c|c|c|c|c|c|}
\hline \multirow[t]{2}{*}{ Dependent variable } & \multicolumn{8}{|c|}{$\Delta$ Quality (demand residual estimate) } \\
\hline & $(1)$ & $(2)$ & $(3)$ & (4) & $(5)$ & $(6)$ & $(7)$ & $(8)$ \\
\hline$\Delta$ Exchange rate & $\begin{array}{c}0.0668^{* *} \\
(0.0263)\end{array}$ & $\begin{array}{c}0.0844^{* * *} \\
(0.0295)\end{array}$ & $\begin{array}{c}0.0516^{* *} \\
(0.0259)\end{array}$ & $\begin{array}{c}0.0785^{* * *} \\
(0.0293)\end{array}$ & $\begin{array}{c}-0.116^{* * *} \\
(0.0331)\end{array}$ & $\begin{array}{c}-0.0931^{* *} \\
(0.0374)\end{array}$ & $\begin{array}{r}-0.00227 \\
(0.0291)\end{array}$ & $\begin{array}{c}0.0116 \\
(0.0340)\end{array}$ \\
\hline$\Delta$ Exchange rate $\mathrm{x}$ differentiated goods & & & & & $\begin{array}{c}0.218^{* * *} \\
(0.0388)\end{array}$ & $\begin{array}{c}0.220^{* * *} \\
(0.0440)\end{array}$ & & \\
\hline$\Delta$ Exchange rate $\mathrm{x} R \& \mathrm{D}$ and advertisement intensive & & & & & & & $\begin{array}{c}0.129 * * \\
(0.0550)\end{array}$ & $\begin{array}{l}0.158^{* *} \\
(0.0619)\end{array}$ \\
\hline$\Delta$ Real GDP & $\begin{array}{c}-0.0431 \\
(0.0569)\end{array}$ & $\begin{array}{c}-0.117 \\
(0.0967)\end{array}$ & $\begin{array}{c}-0.118^{* *} \\
(0.0598)\end{array}$ & $\begin{array}{l}-0.0578 \\
(0.0965)\end{array}$ & $\begin{array}{c}-0.135^{* *} \\
(0.0602)\end{array}$ & $\begin{array}{l}-0.0664 \\
(0.0966)\end{array}$ & $\begin{array}{c}-0.138^{* *} \\
(0.0643)\end{array}$ & $\begin{array}{l}-0.0650 \\
(0.105)\end{array}$ \\
\hline$\Delta$ Production prices & $\begin{array}{c}0.255^{* * *} \\
(0.0414)\end{array}$ & $\begin{array}{c}0.263^{* * *} \\
(0.0431)\end{array}$ & $\begin{array}{c}0.284^{* * *} \\
(0.0419)\end{array}$ & $\begin{array}{c}0.253^{* * *} \\
(0.0431)\end{array}$ & $\begin{array}{c}0.264^{* * *} \\
(0.0425)\end{array}$ & $\begin{array}{c}0.234^{* * *} \\
(0.0436)\end{array}$ & $\begin{array}{c}0.297^{* * *} \\
(0.0435)\end{array}$ & $\begin{array}{c}0.255^{* * *} \\
(0.0446)\end{array}$ \\
\hline Market share & & & $\begin{array}{c}0.138^{* * *} \\
(0.00710)\end{array}$ & $\begin{array}{c}0.694^{* * *} \\
(0.0334)\end{array}$ & $\begin{array}{l}0.143^{* * *} \\
(0.00727)\end{array}$ & $\begin{array}{c}0.712^{* * *} \\
(0.0339)\end{array}$ & $\begin{array}{c}0.145^{* * *} \\
(0.00798)\end{array}$ & $\begin{array}{c}0.726^{* * *} \\
(0.0377)\end{array}$ \\
\hline Observations & $1,346,820$ & $1,346,820$ & $1,346,820$ & $1,346,820$ & $1,328,779$ & $1,328,779$ & $1,175,982$ & $1,175,982$ \\
\hline Estimation & OLS & OLS & OLS & OLS & OLS & OLS & OLS & OLS \\
\hline destination-product \& year fixed effects & Yes & Yes & Yes & Yes & Yes & Yes & Yes & Yes \\
\hline destination-product time trends & No & Yes & No & Yes & No & Yes & No & Yes \\
\hline
\end{tabular}

${ }^{* * *} \mathrm{p}<0.01,{ }^{* *} \mathrm{p}<0.05,{ }^{*} \mathrm{p}<0.1$, robust standard errors in parentheses, standard errors are clustered at the destination-sector (HS 2-digit) level.

All variables are denoted in logs and first differences except Market share. The residual based quality measure relies on the method introduced by

Khandelwal et al. (2013). The construction of the differentiated good dummy is based on Rauch (1999), while the "R\&D and advertisement intensive" dummy equals one for exports from sectors with an R\&D and advertisement intensity (Kugler and Verhoogen, 2012) above the sample median. 
Figure 4: Exchange rate elasticity of the export quality (=\%-response to $1 \%$-appreciation) as a function of the sectoral R\&D and advertisement intensity

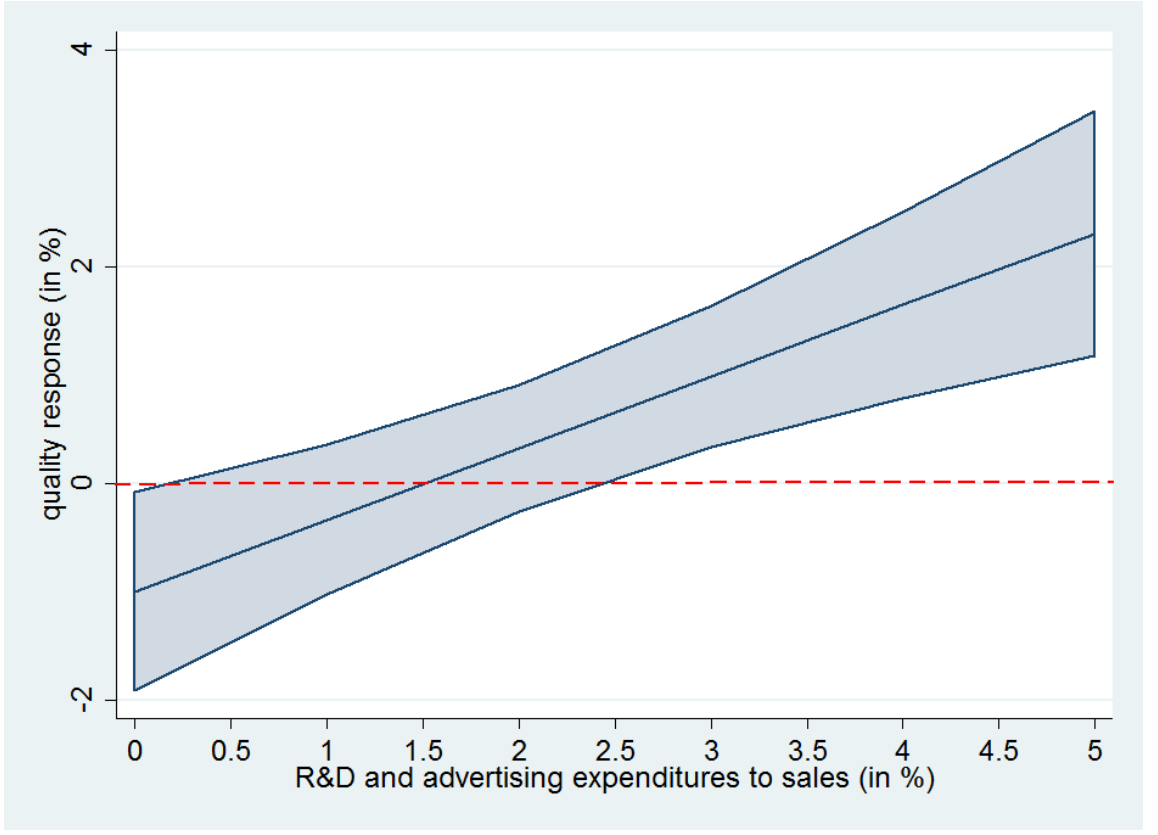

consistent with a quality-augmented Melitz-model in which the product quality provided by the marginal exporter is lower in larger markets, which reduces the average export quality to this destination. This set of estimations takes into account unobserved heterogeneity by considering fixed effects at the HS 8-digit destination level that were dropped due to first differencing.

In Table 3 we test the robustness of the exchange rate driven effect on quality across a variety of empirical specifications. In column 1 we replace the nominal exchange rate with a real exchange rate. The exchange rate effect is preserved even though the significance and size of the exchange rate coefficient is somewhat reduced, probably because of the substantially lower variation of the real exchange rate relative to the nominal rate. ${ }^{17}$ Similarly, the exchange rate result survives with a smaller magnitude in trimmed estimations without observations of the dependent variable above the 99th percentile and below the 1st percentile. This ensures that the main results are not driven by extreme outliers (see column 3). In column 2 we drop the chemical and pharmaceutical sectors from the estimations, which make up almost half of the Swiss export economy in terms of export sales.

\footnotetext{
${ }^{17}$ Moreover, column 1 and 2 of the Appendix Table in Section 7.2 show that the exchange rate driven effect on quality also holds with real rates in further specifications, including column 2 that displays the stronger effect of the real exchange rate on quality in sectors relying more on R\&D and advertisement.
} 
Table 3: Robustness checks of the exchange rate driven effect on product quality

\begin{tabular}{|c|c|c|c|c|c|c|c|c|}
\hline \multirow[t]{2}{*}{ Dependent variable } & \multicolumn{7}{|c|}{$\Delta$ Quality (demand residual estimate) } & \multirow[b]{2}{*}{$(8)$} \\
\hline & $(1)$ & $(2)$ & (3) & (4) & $(5)$ & $(6)$ & $(7)$ & \\
\hline$\Delta$ Quality (t-1) & & & & $\begin{array}{c}-0.6325^{* * *} \\
0.1447\end{array}$ & $\begin{array}{c}-0.2250^{* *} \\
(0.1142)\end{array}$ & & & \\
\hline$\Delta$ Exchange rate (real in (1) / nominal in (2)-(8)) & $\begin{array}{l}0.0396^{*} \\
(0.0213)\end{array}$ & $\begin{array}{c}0.102^{* * *} \\
(0.0339)\end{array}$ & $\begin{array}{c}0.0314^{* *} \\
(0.0143)\end{array}$ & $\begin{array}{c}0.117^{* * *} \\
(0.0327)\end{array}$ & $\begin{array}{c}0.236^{* * *} \\
(0.0778)\end{array}$ & $\begin{array}{c}0.0800^{* * *} \\
(0.0295)\end{array}$ & $\begin{array}{c}0.0802^{* * *} \\
(0.0293)\end{array}$ & $\begin{array}{r}0.590^{* * *} \\
(0.0892)\end{array}$ \\
\hline$\Delta$ Exchange rate $(\mathrm{t}-2)$ & & & & & $\begin{array}{r}0.0608 \\
(0.0442)\end{array}$ & & & \\
\hline$\Delta$ Real GDP & $\begin{array}{l}-0.0840 \\
(0.0961)\end{array}$ & $\begin{array}{r}-0.0219 \\
(0.110)\end{array}$ & $\begin{array}{c}-0.0736^{*} \\
(0.0443)\end{array}$ & $\begin{array}{l}-0.107 \\
(0.126)\end{array}$ & $\begin{array}{c}-0.00524 \\
(0.161)\end{array}$ & $\begin{array}{l}-0.0585 \\
(0.0980)\end{array}$ & & $\begin{array}{c}1.132^{* * *} \\
(0.280)\end{array}$ \\
\hline$\Delta$ Production prices & $\begin{array}{c}0.253^{* * *} \\
(0.0432)\end{array}$ & $\begin{array}{c}0.246^{* * *} \\
(0.0461)\end{array}$ & $\begin{array}{c}0.231^{* * *} \\
(0.0307)\end{array}$ & $\begin{array}{c}0.145^{* * *} \\
(0.0431)\end{array}$ & $\begin{array}{c}0.219^{* * *} \\
(0.0508)\end{array}$ & $\begin{array}{c}0.200^{* * *} \\
(0.0547)\end{array}$ & $\begin{array}{c}0.253^{* * *} \\
(0.0431)\end{array}$ & $\begin{array}{c}0.759^{* * *} \\
(0.122)\end{array}$ \\
\hline$\Delta$ Real GDP per capita & & & & & & & $\begin{array}{c}-0.0276 \\
(0.0983)\end{array}$ & \\
\hline Observations & $1,346,820$ & $1,151,962$ & $1,319,194$ & 900,022 & 996,696 & $1,332,490$ & $1,346,820$ & 959,647 \\
\hline Estimation & OLS & OLS & OLS & GMM & GMM & OLS & OLS & OLS \\
\hline destination-product \& year fixed effects & Yes & Yes & Yes & Yes & Yes & Yes & Yes & Yes \\
\hline destination-product time trends & Yes & Yes & Yes & Yes & Yes & Yes & Yes & Yes \\
\hline Sargan instrument test (p-value) & & & & 0.1980 & 0.1496 & & & \\
\hline
\end{tabular}

${ }^{* * *} \mathrm{p}<0.01,{ }^{* *} \mathrm{p}<0.05,{ }^{*} \mathrm{p}<0.1$, robust standard errors in parentheses, standard errors are clustered at the destination-sector (HS 2-digit) level. column 2 is estimated without the chemical \& pharmaceutical sector, column 3 uses trimmed data (cut-off at top and bottom 1\%-percentile of the the dependent variable). A third lag of quality is included in column 4 but not reported. In column 8 the elasticities from Imbs and Méjean (2015) are replaced with the elasticities from Soderbery (2015) to calculate the quality measure as the dependent variable. 
Interestingly, this tends to increase the size and significance of the exchange rate effect on quality because quality changes in those sectors may be more related to secular trends such as the demand increase for high-end medical products or regulatory changes rather than exchange rate fluctuations. In the next step, we employ the Arellano-Bond GMM estimator in columns 4 and 5 that allows to include lags of the quality measure and to consider the potential endogeneity of the exchange rate. This model thus takes into account the potential for dynamic or gradual adjustments of a dependent variable of interest, in our case the exported product quality. The exchange rate effect remains similar in terms of size and statistical significance after including past values of the quality indicator in column 4. We use third and fourth lags of the quality variable as instruments for the past values of the quality indicator, whereas the exchange rate is treated as exogenous in column 4 . The validity of the used instruments, which corresponds to the null hypothesis in the Sargan overidentification test, cannot be rejected at the 10\%-significance level (p-value is 0.198 as indicated in Table 3). Moreover, errors do not exhibit higher-order autocorrelation so that the requirements for the consistency of the Arellano-Bond estimator are met. In column 5 we treat current exchange rate changes as endogenous. For instance, this potential endogeneity means that distinct appreciation episodes are caused by different factors, such as the euro crisis or a strengthening of the export sector, and therefore do not necessarily exert a uniform effect on the exported quality. We take this concern into consideration and use third lags of exchange rate changes to instrument for current exchange rate changes. ${ }^{18}$ We can again not reject the validity of the instruments ( $\mathrm{p}$-value $=0.15$ ) and there is no higher-order autocorrelation of errors, as required for consistency. There is some evidence for a gradual adjustment of quality to current and past changes of the exchange rate in column 5. This indicates that exporters need some time to fully adjust the export quality in response to exchange rate movements. Dynamic estimations in columns 4 and 5 also reveal that the current quality growth rate depends negatively on its first- and second-order lag, implying a mean-reverting behavior in our quality measure. This implies that periods of quality improvements (or deteriorations) are followed by periods of consolidation in which the quality growth rate returns to its mean value. In column 6 we observe a positive relationship between imported input prices and average export quality absorbing some of the effect previously attributed to changes in overall production prices. This pattern is consistent with exporters switching to more expensive imported inputs to produce higher quality export goods, as shown in the trade literature for developing countries such as

\footnotetext{
${ }^{18}$ Similarly, we also use third lags of quality changes as instruments for their current changes.
} 
China (Bas and Strauss-Kahn, 2015). Changes in real GDP per capita are not found to be related to quality changes in column 7 . In column 8 we recalculate the quality measure using the substitution elasticities (sigmas) from Soderbery (2015). Fortunately, the effect of exchange rate changes on export quality remains qualitatively unaffected so that the main conclusions are robust to the use of this alternative set of widely used sigma estimates. Overall, the results of Table 2 and 3 show that there is a significant and robust increase in the observed quality at the HS 8-digit product category triggered by a CHF appreciation. This is consistent with our theoretical motivation that predicts a firm composition effect after an appreciation, which favors the production of higher quality varieties by more capable firms.

In the set of estimations of Table 4 we employ the quality composition indicator from Section 4.2. The exchange rate effect is estimated fairly precisely and has a systematic positive impact on the average export quality in columns 1 to 4 . This indicates a gain in market shares of more expensive HS 8-digit products within a given HS 4-digit product category as a result of a Swiss Franc appreciation. This exchange rate driven shift towards higher quality goods proxied by unit values is more pronounced for differentiated goods than for homogeneous goods, as can be seen from comparing column 8 with $6 .{ }^{19}$ In quantitative terms, the effect of a $10 \%$ appreciation of the Swiss Franc translates into an increase of the average export quality by about $1 \%$ for differentiated goods (see column 8 ). The stronger and more significant exchange rate effect for products with a greater scope for quality differentiation is arguably indicative of our measure capturing compositional quality changes within a product category. Moreover, the results hold after controlling for the market concentration within HS 4-digit product categories and destinations. Similarly to previous results on disaggregated quality changes (see Table 2 and 3), a more concentrated market structure is associated with larger market shares of higher quality goods, as displayed in columns 4 to 8 . Increases in real GDP in destination countries are negatively related to average export quality, as larger markets are characterized by higher expenditures and thus also allow lower quality goods to survive.

\footnotetext{
${ }^{19}$ Rather than interacting the exchange rate with a differentiated goods dummy as in Table 3 , we perform subsample estimations restricted to homogeneous (columns 5 and 6) or differentiated goods (columns 7 and 8) in Table 4. The reason for applying this different strategy is that in the full sample the quality composition measure at the HS 4-digit level (dependent variable) contains in the majority of cases both differentiated and homogeneous goods. Therefore, the more disaggregated Rauch (1999)-classification dummy cannot be directly applied at this higher aggregation level (HS 4-digit level) and we decided to construct the quality composition measure either with homogeneous (columns 5 and 6) or differentiated (columns 7 and 8) goods only in this set of estimations.
} 
Table 4: Relationship between exchange rate changes and the export quality composition at the HS 4-digit level

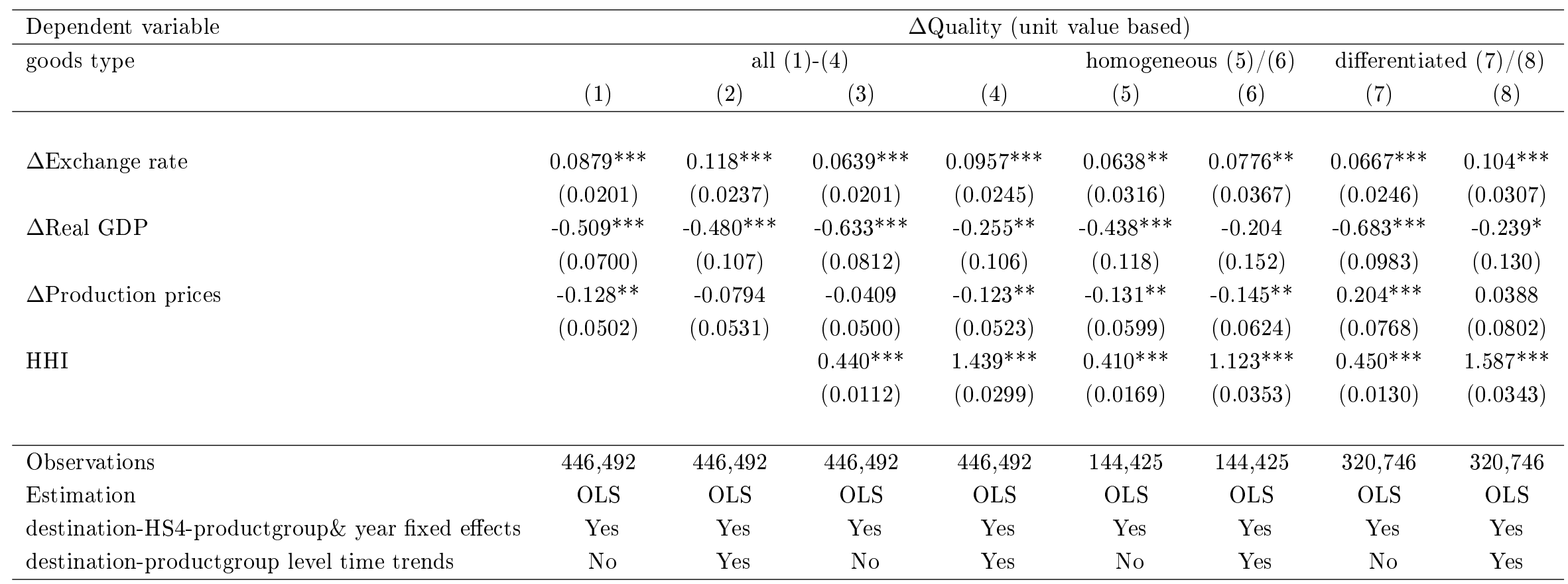

${ }^{* * *} \mathrm{p}<0.01,{ }^{* *} \mathrm{p}<0.05,{ }^{*} \mathrm{p}<0.1$, robust standard errors in parentheses, standard errors are clustered at the destination-sector (HS 2-digit) level.

Columns (1)-4 use the full sample, while the other columns use only homogeneous (5/6) or differentiated goods (7/8) according to

Rauch(1999) classification. 
We conducted a series of robustness checks in Table 5. The positive effect of an appreciation on the average export quality is robust to using bilateral real rather than nominal exchange rate indices in column 1, dropping the chemical and pharmaceutical sector in column 2 and to trimming the sample according to the 1st and 99th percentile of the dependent variable in column 3. ${ }^{20}$ In columns 4 and 5, Arellano and Bond (1991)-models are estimated that allow quality changes to be correlated over time and to gradually adjust to past exchange rate shocks. ${ }^{21}$ From columns 4 and 5 we see that current exchange rate changes are still significant and somewhat stronger quantitatively compared to previous models that did not control for dynamic adjustments. In column 5 current exchange rate changes are considered as endogenous and instrumented by second lags of the exchange rate variable. The results in column 5 suggest that no changes in the average export quality occur in response to past exchange rate fluctuations. Furthermore, test statistics support the consistency of the dynamic models in columns 4 and 5, as errors do not display higher-order autocorrelation and the validity of instruments for the quality and exchange rate variables is not rejected (see p-values of the sargan test in Table 5). Column 6 that includes a control for changes in imported input prices and previous results with our second quality measure indicate that there is no stable relationship between changes in production prices and the quality composition of exports. In column 7 we replace the change in log real GDP with the change in log real GDP per capita. We do not find a positive effect of real GDP per capita on quality, which one would expect when the demand for higher quality rises with the income level (non-homothetic preferences). However, changes in log real GDP and log real GDP per capita are correlated and therefore it is difficult to disentangle the two variables econometrically. As a consequence, the estimated coefficient of the change in log real GDP per capita turns out to be similar to previous results obtained with the change in log real GDP. In the last two columns 8 and 9 we use a quality composition measure recalculated at the narrower HS 6-digit product category. This increases the comparability of products in terms of quality within a given product category. Although smaller in size the exchange rate effect remains highly significant, which ensures that the exchange rate effect on quality is not driven by bundling products that might not necessarily be comparable among one another. The smaller magnitude of the exchange rate coefficient can be explained by the dramatically reduced number of HS 8-digit products within a HS 6-digit product category,

\footnotetext{
${ }^{20}$ see also columns 3 and 4 in the Appendix Table in Section 7.2 for further estimations with real bilateral exchange rates that turn out to be highly significant and similar in size to corresponding specifications with nominal exchange rates.

${ }^{21}$ In column 4 second to fourth lags and in column 5 second and third lags of the quality indicator are used as instruments.
} 
which lowers the variability of the quality composition measure calculated at this more disaggregated level.

Both measures of quality show at different levels of aggregation that the export composition shifts towards goods of higher quality after a currency appreciation. Apart from a pure selection effect of higher quality goods, this might also be the result of firm-level adjustments of product quality. With the data at hand, we cannot disentangle the two possible mechanism in response to currency movements that can lead to higher observed average quality at the product-level. Nonetheless, the fact that the positive effect of an appreciation is also present with the second measure, which is the sum of lagged unit values weighted with changes of market shares within more aggregated product categories, suggests a substantial reallocation effect towards goods that were already previously of higher quality. This is also consistent with quality-augmented Melitz-models that predict a shift towards a priori more capable exporters after a cost shock, while there are no adjustments to cost changes at the firm-level in this framework (see also Manova and Zhang, 2012 in this respect).

\subsection{The effect of quality changes on export growth}

The section aims to explore the effect of quality changes on export sales and volume. As investments in quality are costly, it is useful to study the potentially beneficial effect of quality on aggregate exports. In columns 1 to 4 of Table 6 we employ export unit values as a measure of export quality to examine its effect on disaggregated HS 8-digit level export sales and volume. Please note that we cannot use the residual based quality measure from Section 4.1 since the residuals have been recovered from demand regressions involving export quantities and revenues. The results suggest that export unit values are indeed capturing export quality as these unit values exert a significant positive effect on export sales, as displayed in columns 1 and 2 that also control for the product market share in a given destination and product category (at the HS 4-digit level). Moreover, the positive effect on export sales is particularly pronounced for differentiated goods (see column 4). Quantitatively, a 10\%-increase in prices is associated with $2 \%$ higher export sales in column 1. This positive relationship is consistent with predictions from qualityaugmented trade models with heterogeneous firms and CES (as outlined in Section 3) or linear demand (see Baldwin and Harrigan, 2007 and Manova and Zhang, 2012). Column 3 shows that a higher export price reduces the demanded volume. This negative relationship 
Table 5: Robustness checks of the exchange rate driven effect on the export quality composition

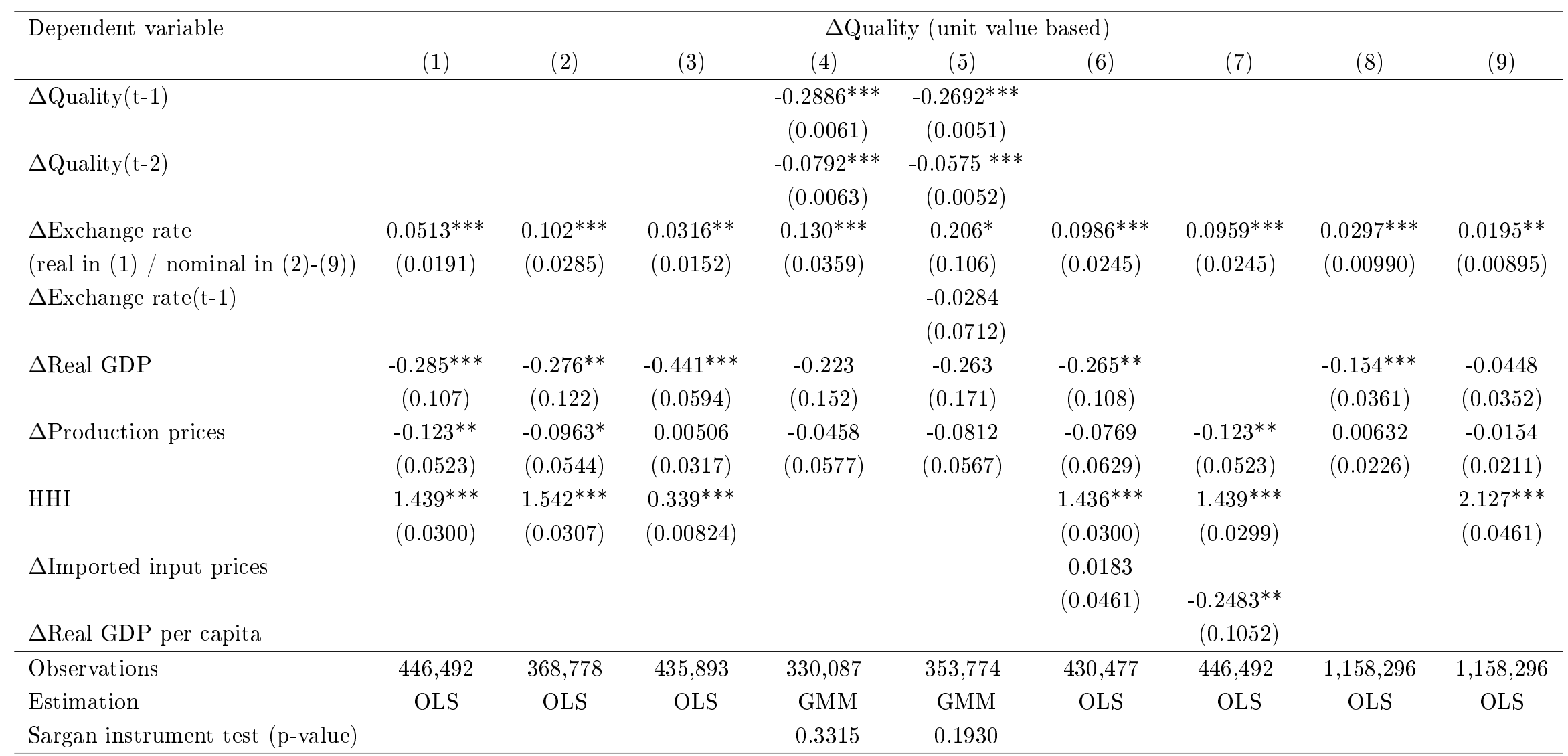

${ }^{* * *} \mathrm{p}<0.01,{ }^{* *} \mathrm{p}<0.05,{ }^{*} \mathrm{p}<0.1$, robust standard errors in parentheses, standard errors in parentheses are clustered at the

destination-sector (HS 2-digit) level. Column 2 is estimated without the chemical \& pharmaceutical sector, column 3 uses trimmed data (cut-off at top and bottom 1\%-percentile of the dependent variable). The quality composition measure in columns (8) and (9) is is calculated at the HS 6-digit level instead of at the HS 4-digit level. All columns contain destination-HS4-productgroup fixed effects and time trends as well as year fixed effects. The third-year lag of quality in column 4 is included but not reported. 
is, however, significantly weaker for differentiated goods (see column 5). This is evidence for higher quality making products less sensitive to prices and, therefore, shielding the Swiss export sector as a whole at least partly from fiercer price competition abroad. In columns 6 and 7 we also observe an increase in export sales at the HS 4-digit level resulting from a higher quality measured with our second quality composition measure from Section 4.2. This implies that the gains in market shares of higher quality products also translates into an overall rise in exports at higher levels of aggregation. In column 8 we also use as a quality measure the log first difference of an average unit value at the HS 4-digit level that is constructed by weighting unit values at the HS 8-digit level with their market shares within a HS 4-digit product category. This measure is arguably more comparable to unit values used in columns 1 to 5 than our other quality composition measure. The fact that the positive impact on export sales is less strong in column 8 (as well as in columns 6 and 7) as opposed to more disaggregated estimations (see columns 1, 2 and 4) indicates a "survival of the fittest"-mechanism at work, with some products with lower perceived quality not only loosing market shares but also exiting destination markets altogether. Table 6 also confirms the greater importance of demand factors relative to exchange rate fluctuations for export sales and volume in line with the literature (Auer and Saure, 2011; Hanslin Grossmann et al., 2016), as can be seen by comparing the size of the positive GDP with the negative exchange rate coefficient. Related to its beneficial effect on aggregate export sales, a higher average export quality is also likely to increase the resilience of the Swiss export sector to currency appreciations due to a lower price sensitivity of higher quality goods, as shown in Table 6. However, firm profits are still likely to fall when the Swiss franc appreciates, as suggested by Lassmann (2013). 
Table 6: Relationship between product quality and export sales/volume

\begin{tabular}{|c|c|c|c|c|c|c|c|c|}
\hline Dependent variable & $\begin{array}{c}\Delta \text { sales } \\
(1)\end{array}$ & $\begin{array}{c}\Delta \text { sales } \\
(2)\end{array}$ & $\begin{array}{c}\Delta \text { volume } \\
(3)\end{array}$ & $\begin{array}{c}\Delta \text { sales } \\
(4)\end{array}$ & $\begin{array}{c}\Delta \text { volume } \\
(5)\end{array}$ & $\begin{array}{c}\Delta \text { sales } \\
(6)\end{array}$ & $\begin{array}{c}\Delta \text { sales } \\
(7)\end{array}$ & $\begin{array}{c}\Delta \text { sales } \\
(8)\end{array}$ \\
\hline$\Delta$ export prices (proxy for quality) & $\begin{array}{c}0.210^{* * *} \\
(0.00766)\end{array}$ & $\begin{array}{l}0.203^{* * *} \\
(0.00741)\end{array}$ & $\begin{array}{c}-0.790 * * * \\
(0.00766)\end{array}$ & $\begin{array}{c}0.0664^{* * *} \\
(0.0106)\end{array}$ & $\begin{array}{c}-0.934^{* * *} \\
(0.0106)\end{array}$ & & & \\
\hline$\Delta$ quality composition at HS4 level & & & & & & $\begin{array}{c}0.0723^{* * *} \\
(0.00317)\end{array}$ & $\begin{array}{c}0.0912^{* * *} \\
(0.00336)\end{array}$ & $\begin{array}{c}0.122^{* * *} \\
(0.00535)\end{array}$ \\
\hline$\Delta$ export prices $\mathrm{x}$ differentiated goods & & & & $\begin{array}{c}0.196^{* * *} \\
(0.0129)\end{array}$ & $\begin{array}{c}0.196^{* * *} \\
(0.0129)\end{array}$ & & & \\
\hline$\Delta$ Exchange rate & $\begin{array}{c}-0.406^{* * *} \\
(0.0321)\end{array}$ & $\begin{array}{c}-0.424^{* * *} \\
(0.0324)\end{array}$ & $\begin{array}{c}-0.406^{* * *} \\
(0.0321)\end{array}$ & $\begin{array}{c}-0.406^{* * *} \\
(0.0323)\end{array}$ & $\begin{array}{c}-0.406^{* * *} \\
(0.0323)\end{array}$ & $\begin{array}{c}-0.438^{* * *} \\
(0.0379)\end{array}$ & $\begin{array}{c}-0.429^{* * *} \\
(0.0378)\end{array}$ & $\begin{array}{c}-0.418^{* * *} \\
(0.0372)\end{array}$ \\
\hline$\Delta$ Real GDP & $\begin{array}{c}1.803^{* * *} \\
(0.116)\end{array}$ & $\begin{array}{c}1.963^{* * *} \\
(0.115)\end{array}$ & $\begin{array}{c}1.803^{* * *} \\
(0.116)\end{array}$ & $\begin{array}{c}1.811^{* * *} \\
(0.117)\end{array}$ & $\begin{array}{c}1.811^{* * *} \\
(0.117)\end{array}$ & $\begin{array}{c}1.580^{* * *} \\
(0.135)\end{array}$ & $\begin{array}{c}1.483^{* * *} \\
(0.136)\end{array}$ & $\begin{array}{c}1.523^{* * *} \\
(0.130)\end{array}$ \\
\hline Market share & & $\begin{array}{c}1.897^{* * *} \\
(0.0165)\end{array}$ & & & & & & \\
\hline HHI & & & & & & & $\begin{array}{c}-0.684^{* * *} \\
(0.0165)\end{array}$ & \\
\hline Observations & $1,380,805$ & $1,380,805$ & $1,380,805$ & $1,361,233$ & $1,361,233$ & 446,492 & 446,492 & 434,769 \\
\hline Estimation & OLS & OLS & OLS & OLS & OLS & OLS & OLS & OLS \\
\hline destination-product \& year fixed effects & Yes & Yes & Yes & Yes & Yes & Yes & Yes & Yes \\
\hline destination-product time trends & Yes & Yes & No & Yes & Yes & Yes & Yes & Yes \\
\hline
\end{tabular}

*** $\mathrm{p}<0.01,{ }^{* *} \mathrm{p}<0.05,{ }^{*} \mathrm{p}<0.1$, robust standard errors in parentheses, standard errors are clustered at the destination-sector (HS 2-digit) level. Column 1 to 5 use export unit values an explaining variable to proxy quality, while Quality is approximated by our composition measure from Section 4.2 in columns 6 and 7. In column 8 we employ a market share weighed unit value at the HS 4-digit level $\left(=\ln \sum\left(s_{i c t} \times p_{i c t}^{f o b}\right)\right)$ in log first differences. The construction of the differentiated good dummy is based on Rauch (1999). 


\section{Conclusions}

The empirical results imply that the average product quality of Swiss exports increases in response to a currency appreciation. Apart from changes in export prices, the input mix and the shift towards higher growth markets, the upward adjustment in quality is thus another channel through which an economy reacts to a loss of competitiveness resulting from a stronger currency. The regressions also convey that the quality improvement occurs through a shift in market shares towards higher quality goods. This indicates the importance of policies that promote product market flexibility and allow for a rapid structural change in the export composition. Furthermore, the exchange rate driven quality effect is particularly pronounced for differentiated goods and in sectors that are intensive in R\&D and advertisement. For instance, while quality does not respond to exchange rate changes in sectors with more homogeneous goods and stronger price competition such as natural resources, a currency appreciation results in significant quality improvements in sectors such as machinery and precision instruments (incl. watches) with a greater scope for quality differentiation. We also find a positive relationship between export quality and export sales that becomes somewhat smaller at higher levels of aggregation. This suggests that there is a more pronounced selection or "survival of the fittest"-effect at higher aggregation levels, with some products dropping out of the export market altogether after a currency appreciation, as shown in Fauceglia et al. (2014a). The link between quality and export sales also indicates that a higher quality reduces the price sensitivity of exports and thereby shields Swiss exporters at least partly from price competition in destination markets. The lower price sensitivity of higher quality goods also increases the overall resilience of the export sector. This characteristic of quality is particularly important in periods of currency appreciations that tend to lower the price attractiveness of exports. The empirical findings are robust to a variety of different specifications, including estimations without the chemical and pharmaceutical sector that make up more than half of the Swiss export sector. From a methodological point of view, the results in this paper suggest that price estimations without quality controls are likely to overstate the extent of exchange rate pass-through irrespective of the type or aggregation level of the data. 


\section{References}

Amiti, M., Itskhoki, O., and Konings, J. (2014). Importers, exporters, and exchange rate disconnect. The American Economic Review, 104(7):1942-1978.

Arellano, M. and Bond, S. (1991). Some tests of specification for panel data: Monte carlo evidence and an application to employment equations. Review of Economic Studies, $58(2): 277$.

Auer, R. and Chaney, T. (2009). Exchange rate pass-through in a competitive model of pricing-to-market. Journal of Money, Credit and Banking, 41:151-175.

Auer, R. and Saure, P. (2011). Chf strength and swiss export performance-evidence and outlook from a disaggregate analysis. Applied Economics Letters, 19(6):521-531.

Baldwin, R. and Harrigan, J. (2007). Zeros, quality and space: Trade theory and trade evidence. NBER Working paper.

Baldwin, R. and Harrigan, J. (2011). Zeros, quality, and space: Trade theory and trade evidence. American Economic Journal: Microeconomics, pages 60-88.

Bas, M. and Strauss-Kahn, V. (2015). Input-trade liberalization, export prices and quality upgrading. Journal of International Economics, 95(2):250-262.

Berman, N., Martin, P., and Mayer, T. (2012). How do different exporters react to exchange rate changes? Quarterly Journal of Economics, 127(1):437-492.

Burstein, A. and Gopinath, G. (2013). International prices and exchange rates. NBER Working paper No 18829.

Caliendo, L. and Parro, F. (2014). Estimates of the trade and welfare effects of nafta. The Review of Economic Studies, page rdu035.

Chen, N. and Juvenal, L. (2014). Quality, trade, and exchange rate pass-through. Working Paper.

Crozet, M., Head, K., and Mayer, T. (2012). Quality sorting and trade: Firm-level evidence for french wine. The Review of Economic Studies, 79(2):609-644.

De Loecker, J., Goldberg, P. K., Khandelwal, A. K., and Pavcnik, N. (2012). Prices, markups and trade reform. Technical report, National Bureau of Economic Research. 
Fan, H., Li, Y. A., and Yeaple, S. R. (2015). Trade liberalization, quality, and export prices. Review of Economics and Statistics, (0).

Fauceglia, D., Lassmann, A., Shingal, A., and Wermelinger, M. (2014a). Backward participation in global value chains and exchange rate driven adjustments of swiss exports. Study on behalf of the State Secretariat for Economic Affairs SECO.

Fauceglia, D., Shingal, A., and Wermelinger, W. (2014b). Natural hedging of exchange rate risk: the role of imported input prices. Swiss Journal of Economics and Statistics (SJES), 150(4):261-296.

Feenstra, R. C. and Romalis, J. (2014). International prices and endogenous quality. Quarterly Journal of Economics, (1-51).

Hallak, J. (2006). Product quality and the direction of trade. Journal of International Economics, 68(1):238-265.

Hallak, J. C. and Schott, P. K. (2008). Estimating cross-country differences in product quality. Quarterly Journal of Economics, 126:417-474.

Hanslin Grossmann, S., Lein, S. M., and Schmidt, C. (2016). Exchange rate and foreign gdp elasticities of swiss exports across sectors and destination countries. Applied Economics, pages $1-17$.

Henn, C., Papageorgiou, C., and Spatafora, M. N. (2013). Export Quality in Developing Countries. Number 13-108. International Monetary Fund.

Hummels, D. and Klenow, P. J. (2005). The variety and quality of a nation's exports. American Economic Review, 3(95):704-723.

Hummels, D. and Skiba, A. (2004). Shipping the good apples out? an empirical confirmation of the alchian-allen conjecture. Journal of Political Economy, 112:1384-1402.

Imbs, J. and Méjean, I. (2015). Elasticity optimism. American Economic Journal: Macroeconomics.

Johnson, R. C. (2012). Trade and prices with heterogeneous firms. Journal of International Economics, 86(1):43-56.

Kaiser, B. and Siegenthaler, M. (2016). The skill-biased effects of exchange rate fluctuations. The Economic Journal, 126(592):756-780. 
Khandelwal, A. K., Schott, P. K., and Wei, S.-J. (2013). Trade liberalization and embedded institutional reform: Evidence from chinese exporters. American Economic Review, 103(6):2169-2195.

Kugler, M. and Verhoogen, E. (2012). Prices, plant size, and product quality. Review of Economic Studies, 79(1):307-339.

Lassmann, A. (2013). Exchange rate transmission and export activity at the firm level. KOF Working Papers No. 331.

Low, P. (2013). The role of services in global value chains. In Global value chains in a changing world, pages $61-81$. WTO.

Manova, K. and Zhang, Z. (2012). Export prices across firms and destinations. Quarterly Journal of Economics, 127:379-436.

Melitz, M. (2003). The impact of trade on intra-industry reallocations and aggregate industry productivity. Econometrica, 71(6):1695-1725.

Moulton, B. R. (1990). An illustration of a pitfall in estimating the effects of aggregate variables on micro units. The review of Economics and Statistics, pages 334-338.

OECD (2012). STAN Input-Output Database Total, Domestic and Imports (database), stats.oecd.org. OECD Paris.

Pierce, J. R. and Schott, P. K. (2012). Concording us harmonized system codes over time. Journal of Official Statistics, 28(1):53-68.

Rauch, J. E. (1999). Networks versus markets in international trade. Journal of international Economics, 48(1):7-35.

Rodriguez-Lopez, J. (2011). Prices and exchange rates: A theory of disconnect. Review of Economic Studies.

Soderbery, A. (2015). Estimating import supply and demand elasticities: Analysis and implications. Journal of International Economics, 96(1):1-17.

Verhoogen, E. A. (2008). Trade, quality upgrading, and wage inequality in the mexican manufacturing sector. The Quarterly Journal of Economics, 123(2):489-530.

Wooldridge, J. M. (2002). Econometric analysis of cross section and panel data. The MIT press. 


\section{Appendix}

\subsection{Theoretical Model}

This section sketches a multi-country partial equilibrium quality-augmented Melitz (2003)model that borrows several features from Crozet et al. (2012), Johnson (2012) and Baldwin and Harrigan (2011). We use the simplest possible CES-framework augmented with quality to derive a prediction about the average quality of exports. At the firm-level, this framework predicts full pass-through and no adjustment in quality because of a constant a priori distribution of capabilities and mark-ups. At the product-level, however, a currency appreciation raises the capability threshold of the marginal exporter. This results in a composition effect that increases average export quality. Consumers in the destination market $c$ exhibit Dixit \& Stiglitz preferences $U_{i}$ over the differentiated varieties $\omega$ within a HS 8-digit level product category $i$, with a constant elasticity of substitution $\sigma>1$, between any two varieties $\omega$. Moreover, the perceived quality $q(\omega)$ of a variety $\omega$ acts as demand shifter. Therefore, preferences $U_{i}$ and demand $x_{i c t}(\omega)$ for a variety $\omega$ in period $t$ within a HS 8-digit product $i$ are of the form:

$$
U_{i}=\left(\int_{\omega \in \Omega_{c t}}^{N} x_{i c t}(\omega) q_{i c t}(\omega) d \omega\right)^{\frac{\sigma}{\sigma-1}}
$$

where $N$ corresponds to the number of existing varieties $\omega$ within a HS 8-digit product $i$. These preferences in (1) lead to a system of demand functions $x_{i c t}(\omega)$ for each variety $\omega$. We formulate a demand $x_{i c t}$ for each variety $\omega$ at the observed product-level $i$ that depends on the product quality $q_{i c t}$ and price $p_{i c t}$ relative to the price index $\widetilde{P_{c t}}$ and income $E_{c t}$ in destination $c$ and year $t$ :

$$
x_{i c t}(\omega)=q_{i c t}^{\sigma-1} p_{i c t}^{-\sigma} \widetilde{P}_{c t}^{\sigma-1} E_{c t},
$$

As standard in this CES-framework, a firm chooses an export price $p_{i c t}$ that is a constant mark-up over marginal cost $m c_{i}$.

$$
p_{i c t}\left(m c_{i}\right)=\left(\frac{\sigma}{\sigma-1}\right) \varepsilon_{c t} \tau_{c t} m c_{i}, \quad \widetilde{p_{i c t}}\left(m c_{i}\right)=\frac{p_{i c t}}{q_{i c t}}=\left(\frac{\sigma}{\sigma-1}\right) \frac{\varepsilon_{c t} \tau_{c t} m c_{i}}{q_{i c t}},
$$

Please denote that $p_{i c t}$ in (9) corresponds to the local-currency price in the destination market. The export price $p_{i c t}$ therefore also reflects iceberg trade costs $\tau_{c t}$, implying that 
$\tau_{c t}>1$ must be shipped in order for one unit of the good to arrive in destination market c. Furthermore, $\varepsilon_{c t}$ is the exchange rate in terms of foreign currency per unit of domestic currency. Dixit-Stiglitz CES preferences lead to full-pass through of exchange rate changes and thus the following relationship $p_{i c t}=\epsilon_{c t} \tau_{c t} p_{i c t}^{f o b}$ between the in our data unobserved $p_{i c t}$ and the observed domestic-currency free on board price $p_{i c t}^{f o b} \cdot \widetilde{p_{i c t}}(c)$ is the qualityadjusted price and is obtained by dividing $p_{i c t}$ by $q_{i c t}$. We can define firm capability $a_{i c t}$ as the ratio between quality and marginal cost: $a_{i c t} \equiv \frac{q_{i c t}}{m c_{i}}$. Intuitively, a capable firm is a high-productivity firm (low $m c_{i}$ ) that sells high-quality products (high $q_{i c t}$ ) demanded by customers. We can thus express the quality-adjusted price and the revenues as a function of firm capability as follows:

$$
\begin{gathered}
\widetilde{p_{i c t}}\left(a_{i c t}(\omega)\right)=\left(\frac{\sigma}{\sigma-1}\right) \frac{\varepsilon_{c t} \tau_{c t}}{a_{i c t}} \\
r_{i c t}\left(a_{i c t}(\omega)\right)=x_{i c t} p_{i c t}=\widetilde{p}_{i c t}\left(a_{i c t}\right)^{1-\sigma} \widetilde{P}_{c t}^{\sigma-1} E_{c t}
\end{gathered}
$$

As as result, more capable firms with a higher $a_{i c t}$ charge lower quality-adjusted prices (see equation 10) and generate higher revenues (see equation 11). In order to export to destination $c$ a firm must cover a fixed cost of market entry $f_{c}$. This leads to the following zero-profit condition:

$$
\frac{1}{\sigma} r_{i c t}\left(a_{i c t}^{*}\right)=f_{c}
$$

The left-hand side of equation (12) corresponds to operating profits that must be equal or higher than market entry costs $f_{c}$ for a firm to serve export market $c$. For the marginal exporter with zero profits equation (12) holds with equality. This determines the minimum capability threshold $a_{i c t}^{*}$ required to export a HS 8-digit product $i$ to destination $c$. Defining attractiveness of an export market $c$ as $A_{c t}=\tau_{c t}^{1-\sigma} \widetilde{P}_{c t}^{\sigma-1} E_{c t}$ and collecting terms in $\eta=$ $\sigma\left(\frac{\sigma}{\sigma-1}\right)^{\sigma-1}$, we obtain the minimum capability $a_{i c t}^{*}$ of the marginal exporter to enter destination $c$ :

$$
a_{i c t}^{*}(\omega)=\varepsilon_{c t}\left(\frac{\eta f_{c}}{A_{c t}}\right)^{\frac{1}{\sigma-1}}
$$

For a given market entry cost $f_{c}$, a more attractive export market $c$ (high $\mathrm{A}_{c t}$ ) due to larger size (higher $E_{c t}$ ), less competition (higher $\widetilde{P}_{c t}$ ) or better accessibility (low $\tau_{c t}$ ) also allows 
less capable firms to profitably enter and reduces $a_{i c t}^{*}$. Equation (13) also makes clear that the minimum level of capability is increasing in the exchange rate. In other words, an exchange rate appreciation $\left(\varepsilon_{c t} \uparrow\right)$ raises the capability of the marginal firm. The observed product-level quality depends on the relationship between firm capability and the provided quality. We assume that this relationship can be described as a power function; $q_{i c t}=a_{i c t}^{\theta}{ }^{22}$ Similarly to Melitz (2003), we compute special averages of the quality $q_{i c t}$ observed at the HS 8-digit product-level:

$$
q_{i c t}\left(\hat{a}\left(a_{i c t}^{*}\right)\right)=\hat{a}^{\theta}\left(a_{i c t}^{*}\right)=\left(\frac{1}{1-G\left(a_{i c t}^{*}\right)} \int_{a_{i c t}}^{\infty} a_{i c t}^{\sigma-1} d G\left(a_{i c t}\right)\right)^{\frac{\theta}{\sigma-1}}
$$

Equation (14) shows that the quality level $q_{i c t}$ rises whenever capability and product quality are positively correlated or, equivalently, that is if $\theta>0$ holds . Equation (13) and (14) indicate how the exchange rate and quality are tied together. A currency appreciation increases the capability of the marginal exporter (see equation 13) and shifts the composition towards more capable firms that produce higher-quality products (see equation 14). This results in rising market shares of higher quality varieties and an increase in the average export quality at the observed product-level. The next hypothesis summarizes this result: Hypothesis: A currency appreciation increases the observed quality of a product through a composition effect that favors more capable firms producing higher quality varieties.

This theoretical result is entirely driven by a selection effect in the firm-product composition after an exchange rate shock. The exchange rate effect does not materialize because firms adjust their quality in response to a stronger exchange rate. A similar composition effect is also present in the initial Melitz (2003)-model that emphasizes firm productivity instead of capability. In the original Melitz (2003)-model, an exchange appreciation would also raise the productivity threshold and force the least productive exporters to exit (see also Rodriguez-Lopez (2011)). Our composition effect also bears similarities with the competitive model proposed by Auer and Chaney (2009) in which low-quality producers also pull out of the export market as a result of an exchange rate appreciation.

\footnotetext{
${ }^{22}$ The power function is a convenient mathematical formulation that allows to obtain tractable model solutions and to describe any arbitrary (e.g. a positive) relationship between firm capability and product quality (see for instance Johnson, 2012 for an application in a very similar quality context).
} 


\subsection{Appendix Table: Robustness to real exchange rate movements}

Dependent variable

(1)

(1)

(2)

$\Delta$ Quality

Quality measure

demand residual (HS $)$

S8) $(1 / 2$

$0.0450^{* *}$

$\begin{array}{ll}(0.0215) & (0.0276) \\ 0.146^{* * *}\end{array}$

$\Delta$ Real exchange rate

$\Delta$ Real exchange rate $\mathrm{x}$ differentiated goods

(0.0345)

$\Delta$ Real GDP

$-0.142$

(0.0964)

$-0.0959$

(0.0965)

$0.263^{* * *}$

(0.0431)

Market Share

$\Delta$ Production prices$$
(0.0431)
$$

$0.242^{* * *}$

(0.0437)

$0.712^{* * *}$

(0.0339)
(4)

(3)

HS4) $(3 / 4)$

unit value based (HS4) $(3 / 4)$

$$
\begin{array}{cc}
0.0732^{* * *} & 0.0585^{* *} \\
(0.0180) & (0.0246)
\end{array}
$$

$\begin{array}{cc}-0.505^{* * *} & -0.267^{* *} \\ (0.108) & (0.132) \\ -0.0793 & 0.0390 \\ (0.0531) & (0.0802)\end{array}$

$1.587^{* * *}$

(0.0343)

HHI

$1.587^{* * *}$
$(0.0343)$

\begin{tabular}{lcccc}
\hline Observations & $1,346,820$ & $1,328,779$ & 446,492 & 320,746 \\
Estimation & OLS & OLS & OLS & OLS \\
\hline
\end{tabular}

${ }^{* * *} \mathrm{p}<0.01,{ }^{* *} \mathrm{p}<0.05,{ }^{*} \mathrm{p}<0.1$, robust standard errors in parentheses, standard errors

in parentheses are clustered at the destination-sector (HS 2-digit) level. Column 4 is estimated with differentiated goods only. All columns contain destination-HS4-productgroup fixed effects and time trends as well as year fixed effects. 

In der Reihe „Strukturberichterstattung“ des Staatssekretariats für Wirtschaft sind seit 2000 erschienen:

$1 \quad$ Arvanitis, S. u.a. (2000) Die preisliche Wettbewerbsfähigkeit der schweizerischen Wirtschaftszweige

2 Arvanitis, S. u.a. (2001) Untersuchung der internationalen Wettbewerbsfähigkeit der 22. schweizerischen Wirtschaftszweige anhand einer „Constant Market Shares“-Analyse der Exportanteile

3 Raffelhüschen, B. u.a. (2001) Zur Nachhaltigkeit der schweizerischen Fiskal- und Sozialpolitik: Eine Generationenbilanz (ohne Software GAP)

4 Arvanitis, S. u.a. (2001) Unternehmensgründungen in der schweizerischen Wirtschaft 126.

5 Arvanitis, S. u.a. (2001) Innovationsaktivitäten in der Schweizer Wirtschaft. Eine Analyse $\quad 34$. der Ergebnisse der Innovationserhebung 1999

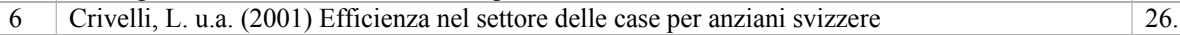

7 Hollenstein, H. (2001) Die Wirtschaftsbeziehungen zwischen der Schweiz und Osteuropa 23.

8 Henneberger, F. u.a. (2001) Internationalisierung der Produktion und sektoraler Strukturwandel: 21. Folgen für den Arbeitsmarkt

9 Arvanitis, S. u.a. (2002) Finanzierung von Innovationsaktivitäten. Eine empirische Analyse $\quad 22$. anhand von Unternehmensdaten

10 Arvanitis, S. u.a. (2002) Qualitätsbezogene und technologische Wettbewerbsfähigkeit der schweizerischen Industriezweige. Beurteilung auf Grund der Export- bzw. Importmittelwerte und der Hochtechnologieexporte

11 Ott, W. u.a. (2002) Globalisierung und Arbeitsmarkt: Chancen und Risiken für die Schweiz 28.

12 Müller, A. u.a. (2002) Globalisierung und die Ursachen der Umverteilung in der Schweiz. $\quad 24$. Analyse der strukturellen und sozialen Umverteilungen in den 90-er Jahren mit einem Mehrländer-Gewichtsmodell

13 Kellermann, K. (2002) Eine Analyse des Zusammenhangs zwischen fortschreitender Globalisierung und der Besteuerung mobiler Faktoren nach dem Äquivalenzprinzip

14 Infras (2002) Globalisierung, neue Technologien und struktureller Wandel in der Schweiz $\quad 28$.

15 Fluckiger, Y. u.a. (2002) Inégalité des revenues et ouverture au commerce extérieur $\quad 20$.

16 Bodmer, F. (2002) Globalisierung und Steuersystem in der Schweiz 22.

17 Arvanitis, S. u.a. (2003) Die Schweiz auf dem Weg zu einer wissensbasierten Ökonomie: $\quad 28$. eine Bestandesaufnahme

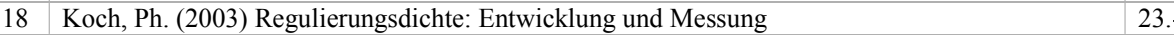

19 Iten, R. u.a. (2003) Hohe Preise in der Schweiz: Ursachen und Wirkungen $\quad 36$.

20 Kuster, J. u.a. (2003) Tourismusdestination Schweiz: Preis- und Kostenunterschiede zwischen 23. der Schweiz und EU

21 Eichler, M. u.a. (2003) Preisunterschiede zwischen der Schweiz und der EU. Eine empirische 34. Untersuchung zum Ausmass, zu Erklärungsansätzen und zu volkswirtschaftlichen Konsequenzen

22 Vaterlaus, St. u.a. (2003) Liberalisierung und Performance in Netzsektoren. Vergleich der Liberalisierungsart von einzelnen Netzsektoren und deren Preis-Leistungs-Entwicklung in ausgewählten Ländern

23 Arvanitis, S. u.a. (2003) Einfluss von Marktmobilität und Marktstruktur auf die Gewinn- $\quad 23$. margen von Unternehmen - Eine Analyse auf Branchenebene

24 Arvanitis, S. u.a. (2004) Innovationsaktivitäten in der Schweizer Wirtschaft - Eine Analyse 28. der Ergebnisse der Innovationserhebung 2002

25 Borgmann, Ch. u.a. (2004) Zur Entwicklung der Nachhaltigkeit der schweizerischen Fiskal- $\quad 20$. und Sozialpolitik: Generationenbilanzen 1995-2001

26D de Chambrier, A. (2004) Die Verwirklichung des Binnenmarktes bei reglementierten Berufen: Grundlagenbericht zur Revision des Bundesgesetzes über den Binnenmarkt

26F de Chambrier, A. (2004) Les professions réglementées et la construction du marché intérieur: rapport préparatoire à la révision de la loi sur le marché intérieur

\begin{tabular}{l|l|l}
27 & Eichler, M. u.a. (2005) Strukturbrüche in der Schweiz: Erkennen und Vorhersehen & 23.
\end{tabular}

28 Vaterlaus, St. u.a. (2005) Staatliche sowie private Regeln und Strukturwandel $\quad 32$.

29 Müller, A. u.a. (2005) Strukturwandel - Ursachen, Wirkungen und Entwicklungen $\quad 24$.

30 von Stokar Th. u.a. (2005) Strukturwandel in den Regionen erfolgreich bewältigen $\quad 22$.

31 Kellermann, K. (2005) Wirksamkeit und Effizienz von steuer- und industriepolitischen $\quad 22$. Instrumenten zur regionalen Strukturanpassung 
32 Arvanitis, S. u.a. (2005) Forschungs- und Technologiestandort Schweiz: Stärken-/Schwächenprofil im internationalen Vergleich

33E Copenhagen Economics, Ecoplan, CPB (2005) Services liberalization in Switzerland

34 Arvanitis, S. u.a. (2007) Innovationsaktivitäten in der Schweizer Wirtschaft - Eine Analyse der Ergebnisse der Innovationsserhebung 2005

35/1 Brunetti, A., und S. Michal (eds.) - 2007 - Services Liberalization in Europe: Case Studies (vol. 1) 37.

35/2 Brunetti, A., und S. Michal (eds.) - 2007 - Services Liberalization in Europe: Case Studies (vol. 2) 26.

36/1 Balastèr, P., et C. Moser (éd.) - 2008 - Sur la voie du bilatéralisme: enjeux et conséquences (vol.1) 38.

36/2 Balastèr, P., et C. Moser (éd.) - 2008 - Sur la voie du bilatéralisme: enjeux et conséquences (vol. 2.41.

37 Kellermann, K. (2007) Die öffentlichen Ausgaben der Kantone und ihrer Gemeinden im $\quad 25$. Quervergleich

38 Ecoplan (2008) Benchmarking: Beispiel öffentlicher Regionalverkehr

39 Filippini, M. \& M. Farsi (2008) Cost efficiency and scope economies in multi-output utilities 18. in Switzerland

40 Kuster, J., und H.R. Meier (2008) Sammlung von Altpapier durch die Gemeinden statistische Benchmarking-Methoden im Test

41 Frick, A. (2008) Benchmarking öffentlicher Leistungen anhand des Fallbeispiels "Berufsbildung": 14. Vergleich der kantonalen Ausgaben für die Berufsbildung

42 Schoenenberger, A. e.a. (2009) Efficacité technique des exploitations forestières publiques $\quad 25$. en Suisse

43 Arvanitis, S. u.a. (2008) Innovation und Marktdynamik als Determinanten des Strukturwandels

44/1 Worm, H. u.a. (2009) Evaluation Kartellgesetz: Volkswirtschaftliche Outcome-Analyse

44/2 Hüschelrath, K. u.a. (2009) Evaluation Kartellgesetz: Fallstudien zu den Wirkungen des Kartellgesetzes

44/3 Baudenbacher, C. (2009) Evaluation Kartellgesetz: Institutionelles Setting Vertikale Abreden Sanktionierung von Einzelpersonen Zivilrechtliche Verfahren - with an English summary

44/4 Heinemann, A. (2009) Evaluation Kartellgesetz: Die privatrechtliche Durchsetzung des Kartellrechts

45 Hulliger, B. u.a. (2009) Erste Auswirkungen der Abschaffung der Buchpreisbindung Technischer Bericht und Vertiefung

46 Arvanitis, S. u.a. (2010) Innovationsaktivitäten in der Schweizer Wirtschaft - Eine Analyse der Ergebnisse der Innovationsserhebung 2008

47/1 Arvanitis, S. u.a. (2011) Exportpotenziale im Dienstleistungssektor (Band 1)

47/2 Moser, P. u.a. (2011) Exportpotenziale im Dienstleistungssektor (Band 2)

47/3 Delimatsis, P. (2011) Exportpotenziale im Dienstleistungssektor (Band 3)

47/4 Egger, P., und G. Wamser (2011) Exportpotenziale im Dienstleistungssektor (Band 4)

48/1 Vaterlaus, St. u.a. (2011) Produktivität und Finanzierung von Verkehrsinfrastrukturen (Band 1)

48/2 Peter, M. u.a.(2011) Produktivität und Finanzierung von Verkehrsinfrastrukturen (Band 2)

48/3 Suter, St. u.a. (2011) Produktivität und Finanzierung von Verkehrsinfrastrukturen (Band 3)

48/4 Bruns, F. u.a. (2011) Produktivität und Finanzierung von Verkehrsinfrastrukturen (Band 4)

48/5 Müller, U. u.a. (2011) Produktivität und Finanzierung von Verkehrsinfrastrukturen (Band 5)

49 Arvanitis, S. u.a. (2013) Innovationsaktivitäten in der Schweizer Wirtschaft - Eine Analyse der Ergebnisse der Innovationserhebung 2011

50/1 Eichler, M. u.a. (2013) The Financial Sector and the Economy: A Pillar or a Burden? (Band 1)

50/2 Kellermann, K. und Schlag, C.-H. (2013) Wird die Wertschöpfung der Kreditinstitute zu hoch ausgewiesen? (Band 2)

50/3 Abrahamsen, Y. u.a. (2013) Die Rolle der Banken bei der Transformation von Finanz- in Sachkapital (Band 3)

50/4 Kellermann, K. und Schlag, C.-H. (2013) Wofür und für wen spart die Schweiz? - Der Einfluss der finanziellen Globalisierung auf die Vermögensbildung und -struktur der Schweiz (Band 4)

50/5 Dembinski, P. e.a. (2013) Productivité et rentabilité du capital physique et financier - Analyse statistique exploratoire des données micro-économiques suisses (Band 5)

51 Arvanitis, S. u.a. (2014) Die Entwicklung der Innovationsaktivitäten in der Schweizer Wirtschaft 15. 1997-2012

52 Arvanitis, S. u.a. (2014) Auswirkungen der Finanz- und Wirtschaftskrise von 2008 auf die Schweizer Wirtschaft - Eine Analyse auf der Basis von Unternehmensdaten - nur elektronische Fassung 
53/1 Nathani, C. u.a. (2014) Die Volkswirtschaftliche Bedeutung der globalen Wertschöpfungsketten für die Schweiz - Analysen auf Basis einer neuen Datengrundlage - Schwerpunktthema:

Die Schweiz in den globalen Wertschöpfungsketten

53/2 Fauceglia, D. u.a. (2014) Backward Participation in Global Value Chains and Exchange Rate Driven Adjustments of Swiss Exports - Schwerpunktthema:

Die Schweiz in den globalen Wertschöpfungsketten

53/3 Arvanitis, S. u.a. (2014) Die Determinanten und Auswirkungen von intra-betrieblichen Leistungsverflechtungen - Schwerpunktthema: Die Schweiz in den globalen Wertschöpfungsketten

53/4 Morlok, M. u.a. (2014) Der Einfluss internationaler Wertschöpfungsketten auf berufliche Tätigkeiten und Qualifikationen in der Schweiz - Schwerpunktthema: Die Schweiz in den globalen Wertschöpfungsketten

53/5 Böhmer, M. und Weiss, J. (2014) Forschungs- und Technologieintensität in der Schweizer Industrie - Schwerpunktthema: Die Schweiz in den globalen Wertschöpfungsketten

54/1 Eberli, A. u.a. (2015) Beitrag branchenspezifischer Effekte zum Wachstum der Schweizer Arbeitsproduktivität - Schwerpunktthema: Wachstum der Schweizer Volkswirtschaft

54/2 Ehrentraut, O. u.a. (2015) Die Bedeutung des Humankapitals für die Entwicklung der Arbeitsproduktivität und das Wirtschaftswachstum - Schwerpunktthema: Wachstum der Schweizer Volkswirtschaft

54/3 Kaiser, B. und Siegenthaler, M. (2015) The Productivity Deficit of the Knowledge-Intensive Business Service Industries in Switzerland - Schwerpunktthema: Wachstum der Schweizer Volkswirtschaft

54/4 Jäger, Ph. u.a. (2015) Der Zusammenhang zwischen dem technischen Fortschritt, der Investitions- 12. tätigkeit und der Produktivitätsentwicklung - Schwerpunktthema: Wachstum der Schweizer Volkswirtschaft

54/5 Fuest, A. u.a. (2015) Der Zusammenhang zwischen der Offenheit und der Produktivitätsentwicklung - Schwerpunktthema: Wachstum der Schweizer Volkswirtschaft

54/6 Marti, M. u.a. (2017) Regionale Analyse der Arbeitsproduktivität - nur elektronische Fassung

55 Arvanitis, S. u.a. (2016) Die Entwicklung der Innovationsaktivitäten in der Schweizer Wirtschaft 17. 1997-2014

56/1 Erhardt, T. u.a. (2017) Frankenaufwertung und Exportstruktur - Schwerpunktthema: Die Schwei- 23. zer Wirtschaft in einem schwierigen Währungsumfeld

56/2 Fauceglia, D. u.a. (2017) Exchange rate fluctuations and quality composition of exports: Evidence 10. from Swiss product-level data - Schwerpunktthema: Die Schweizer Wirtschaft in einem schwierigen Währungsumfeld 
Federal Department of Economic Affairs,

Education and Research EAER

State Secretariat for Economic Affairs SECO

Economic Policy Directorate

Holzikofenweg 36, 3003 Bern

Distribution: Tel. +41 (0)58 46408 60, Fax +41 (0)58 46350 01, 10.2017100

www.seco.admin.ch, wp-sekretariat@seco.admin.ch

ISBN 978-3-905967-35-7 